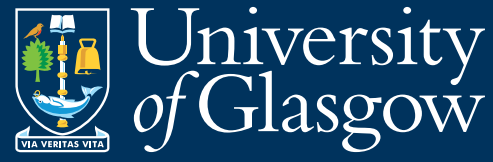

Adam Smith

Business School

WORKING

PAPER

SERIES

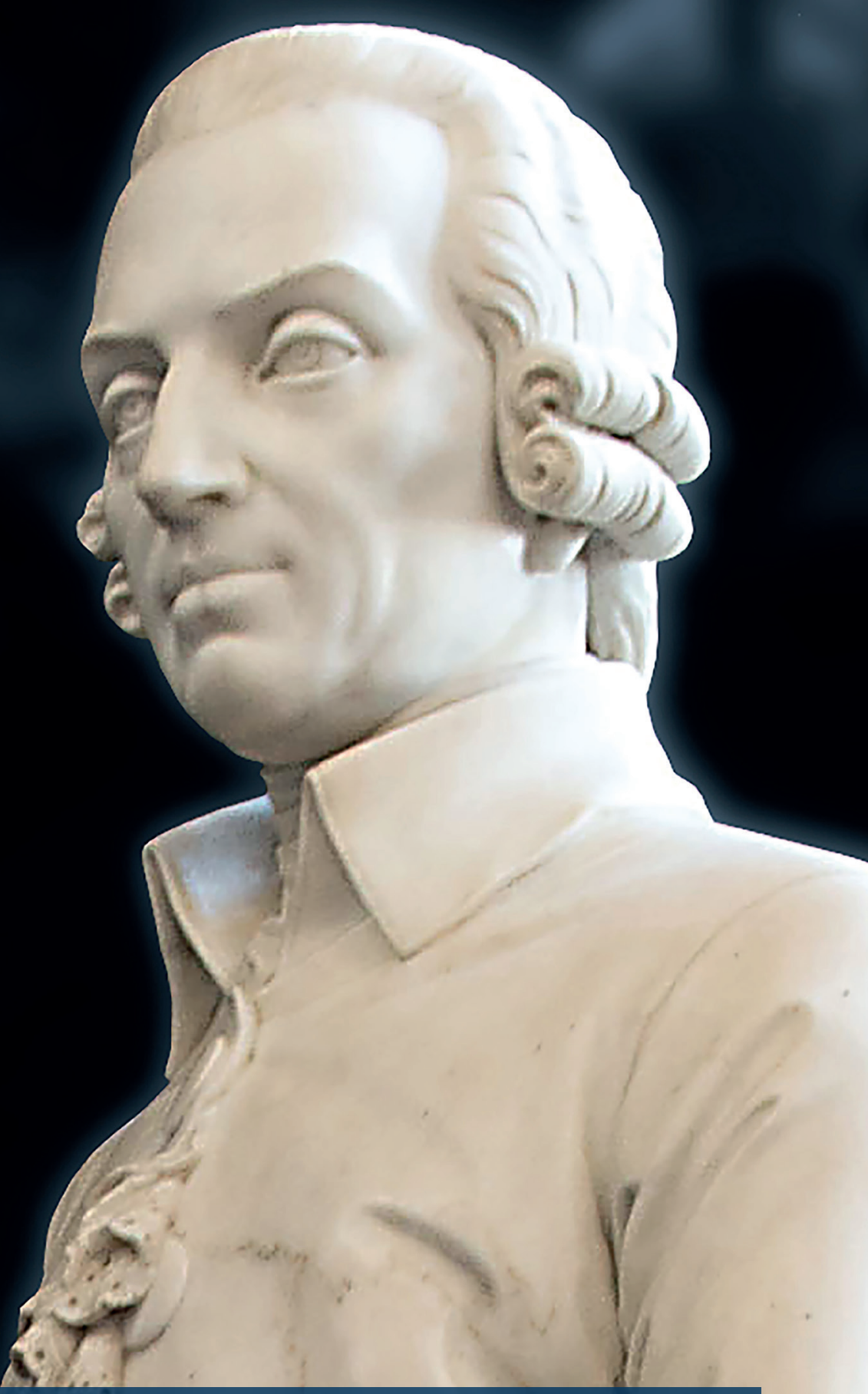

Political Sentiment and Syndicated Loan Borrowing Costs of Multinational Enterprises

Panagiotis Karavitis and Pantelis Kazakis

Paper no. 2020-29

December 2020 


\title{
Political Sentiment and Syndicated Loan Borrowing Costs of Multinational Enterprises
}

\author{
11 December 2020 \\ Panagiotis Karavitis ${ }^{+}$ \\ University of Glasgow, Adam Smith Business School \\ Pantelis Kazakis ${ }^{\S}$ \\ University of Glasgow, Adam Smith Business School
}

\footnotetext{
We are grateful to Woon Sau Leung, George Panos, Pascalis Raimondos-Møller, Antonios Siganos, Serafeim Tsoukas for their useful comments. We are indebted to Sotirios Kokas for sharing his Dealscan data set and matching codes.

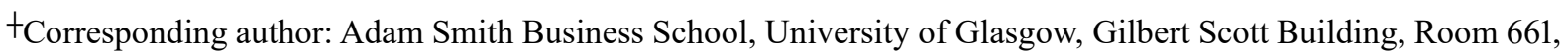
University Avenue, G12 8QQ, UK. E-mail: Panagiotis.Karavitis@glasgow.ac.uk.

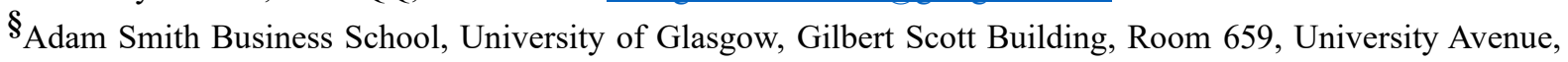
G12 8QQ, UK. E-mail: Pantelis.Kazakis@glasgow.ac.uk.
} 


\title{
Political Sentiment and Syndicated Loan Borrowing Costs of Multinational Enterprises
}

\begin{abstract}
International business literature widely recognizes that political forces play a crucial role in modern corporations. Yet, rare are the studies of how foreign operations mitigate the detrimental effect that firm-level political exposure has on the cost of lending. We study such channels in a sample of U.S. corporations with foreign subsidiaries in 69 countries. We proxy firm-level political exposure via political sentiment. We show that firms with lower political sentiment (i.e., higher political exposure) have a higher cost of lending. We document that multinational enterprises with a presence in many countries, and those having an extended network of foreign subsidiaries can lower the harmful effects of increased political uncertainty. This outcome also holds in the presence of foreign economies of scale, and when multinational corporations have foreign subsidiaries in countries with higher political polarization.
\end{abstract}

Keywords: political sentiment; syndicated loans; multinationals; international diversification

JEL codes: G21; G18; P16 


\section{Introduction}

The political environment a firm is operating in is very volatile. Changes in legislation or regulation can have an imminent impact on a firm's operations (Boubakri, Mansi \& Saffar, 2013). Recent examples include trade wars and the United Kingdom's withdrawal from the European Union (Brexit). Apart from aggregate political shocks and uncertain events, such as elections, the tone politicians might use towards specific sectors or firms might have tangible consequences for them. As firms differ in organizational structure, industry, and foreign operations, the impact of political shocks is not homogenous.

Building on prior international finance literature studying how political forces affect the business environment (e.g., Boubakri, et al., 2013; Qi \& Nguyen, 2020), we study how firm-level political shocks, measured via political sentiment, affect the cost of syndicated loans and foreign operations. In doing so, we use a component from the Hassan et al. (2019) database, political sentiment, which captures good or bad news regarding a firm's exposure to political events. Thus, we enhance our understanding of how political shocks affect loan costs for multinational enterprises (MNEs). This issue is of interest to investors (domestic and international) as well as to MNEs seeking international partners. Therefore, it is crucial to understand the mechanisms under which an MNE can mitigate or even eliminate the effects of political shocks on the cost of capital.

According to Giambona, Graham \& Harvey (2017), political sentiment in management teams proxies for the mean political exposure of firms. Political sentiment also accounts for managers' potential biases. According to Jiang et al. (2019), “...corporate managers are not immune from behavioral biases. As a result, they can be overly optimistic or pessimistic relative to fundamentals, leading to irrational market outcomes..." According to Giambona et al. (2017), manager sentiment captures an important part of political uncertainty. 
In this study, we argue that lower exposure to political shocks, expressed by more positive political sentiment, translates into a lower cost of lending. ${ }^{1}$ A firm with lower political exposure could either have direct political links or operate in a politically favorable business environment. On one hand, the relevant literature stresses the influence of political connections on firms (Chen, Ding \& Kim, 2010; Brockman, Rui \& Zou, 2013; Sojli \& Tham, 2017). On the other hand, firms in favorable business environments - for example, under the leadership of a "business-friendly" political party (not necessarily a right-wing party) — enjoy economic benefits (see e.g., Julio \& Yook, 2012).

To examine the relationship between political sentiment and the cost of syndicated loans for firms with foreign operations, we construct a unique dataset from Dealscan, Call Reports from the Federal Reserve Board of Governors (FRB), Compustat, and Orbis from 2002 to 2015. Importantly, we utilize a component from a new firm-level political uncertainty database of Hassan et al. (2019). The authors employ conference call transcripts of public U.S. firms and perform textual analysis to construct several indexes of political risk and sentiment. This is different from previous academic work that mostly relies on the Baker et al. (2016) policy uncertainty index, which varies at the country-year level. The advantage of working with firm-level data is that we can isolate the net-idiosyncratic impact that political exposure and its interaction with foreign operations have on a firm's cost of loans.

We find that firm-level political sentiment is highly correlated with the cost of loan syndicates. In our most restrictive baseline model, we find that a one-standard-deviation decrease in political sentiment - lower values indicate more negative sentiment — precede an increase of all-in-spreaddrawn (AISD) of about 4.4 basis points. This implies an increase of about $2.9 \%$ compared to the mean value of AISD, which translates to about $\$ 1.7$ million. ${ }^{2}$ However, MNEs with a strong international presence can mitigate or even eliminate the negative effects of low political sentiment. Our findings show that the average MNE, with a presence in 12 countries or with 43 foreign subsidiaries, eliminates

\footnotetext{
${ }^{1}$ According to Pérez-Martín et al. (2018), banks utilize new technologies (e.g., artificial intelligence and machine learning), to infer uncertainty and risk about a firm.

${ }^{2}$ Calculated as $2.9 \% * 57$ million.
} 
the negative effects of low political sentiment. That is, although negative political sentiment is priced higher in the loan market, MNEs mitigate the effect with increased international presence.

Our granular data and research design allow us to use a multicountry setting to explore how political risk affects the cost of loans. Contrary to concurrent research (see Gad et al., 2019; Saffar et al., 2019) our study considers MNEs' foreign operations strategies. If not included in the model, this could be an omitted factor. Including a full set of time-invariant and time-varying fixed effects, along with relevant controls suggested in the literature, might still yield biased results. Although we do not have a natural experiment to solve this issue, we rely on the international coverage of our database to perform an instrumental variables analysis. Motivated by the relevant literature that identifies the impact of conflict on political risk (Henisz, Mansfield \& Von Glinow, 2010), and especially for MNEs (Darentelli \& Hill, 2016), we construct a new instrument for MNE political exposure based on the external conflict of the country in which its subsidiaries operate. We perform several sensitivity tests to examine the robustness of our findings. Specifically, we control for corporate governance, the exclusion of the top three lead arrangers, firm volatility, and credit ratings. Finally, we construct the total cost of borrowing following Berg et al. (2016) and rerun all models. Our results hold.

Our paper makes several contributions to the international finance literature. First, by utilizing a unique dataset with granular information about firm-level political exposure, we provide new evidence about the interaction between political exposure, cost of loans, and foreign operations. Our granular data and research design allow us to isolate how firm-specific political exposure affects the cost of loans and how firms diversify this via foreign operations. Thus, we add to the literature examining political heterogeneities, the cost of funding, and foreign operations (Beaulieu, Cosset \& Essaddam, 2005; Qi \& Nguyen, 2020).

Second, we provide new evidence about the international diversification of political shocks. We first show that MNEs with a significant presence in multiple countries and/or with an extended network of foreign subsidiaries, mitigate the harmful effects of low political sentiment on the cost of loans. Further, we provide evidence that foreign subsidiaries in the same industry (i.e., foreign economies of 
scale) and/or in countries with high political polarization drive this result. Our finding is in line with previous literature stating that not all types of international geographic diversification benefit MNEs. According to Doukas and Lang (2003), international diversification is beneficial only when parent and subsidiary companies are in core-related businesses.

Third, MNE operations allow us to examine the role of potential across-countries tax avoidance. Hasan, Hoi, Wu \& Zhang (2014), using a single-country dataset, show that banks penalize tax avoidance by raising the cost of lending. According to Brühne \& Jacob (2019) “...foreign operations can determine the general availability of cross border tax avoidance opportunities..." and "...Firms with foreign operations in low-tax jurisdictions are able to set up beneficial tax structures in these countries at lower cost..." Utilizing Orbis, we construct proxies for foreign operations for U.S. MNEs — specifically, the number of countries with subsidiaries, the number of foreign subsidiaries, and (in untabulated results) the number of low-tax subsidiaries. We find that MNEs with extensive foreign operations mitigate the negative effects of political shocks on loan cost. This extends and complements Hasan et al. (2014) by providing evidence that foreign operations, which enable cross-border taxavoidance opportunities, are diversification tools for MNEs.

Fourth, being aligned with the international finance literature that documents an increase in firm financial exposure due to external conflicts (see e.g., Henisz et al., 2010; Darenteli \& Hill, 2016), and taking advantage of our rich dataset of MNEs subsidiaries, we construct a new instrument to proxy for firm-level political shocks. Specifically, we use the country-level index of external conflict from ICRG to construct a firm-level weighted-average political exposure index based on the external conflict values of subsidiary countries.

Our results have general implications for business practices in a global setting. Understanding how firm-level exposure due to political events affects the cost of lending for MNEs should be of interest to domestic and international investors. Moreover, the channels through which MNEs can diversify negative political sentiment should be of interest to MNEs seeking international partners. 


\section{Literature review and hypotheses development}

Well-established literature examines how political forces influence the business environment, as well as how firms' strategies respond to these political forces (e.g., Faccio, 2006). Politicians and political institutions, through their decisions, shape firms' political environments (Boubakri et al., 2013). Ideally, political decisions should be exogenous to a firm. Nevertheless, firms spend a non-negligible portion of their resources to internalize political factors, for example through political connections.

The relevant literature widely recognizes two types of political connections: direct, where major shareholders, high-ranking executives, and/or board members have political affiliations; and indirect which is linked with lobbying expenditures (Bertrand, Bombardini, Fisman \& Trebbi, 2020) and/or campaign contributions (Ansolabehere, de Figueiredo \& Snyder, 2003). Politically connected firms have several benefits. For example, they may face lower chances of audits, court orders, or penalties. They might also have insider information regarding imminent laws, and they can alter operations accordingly (Bertrand, Bombardini \& Trebbi, 2014; Wellman, 2017).

Additionally, Faccio (2006) finds a significant increase in corporate value when officers or large shareholders enter politics. Similarly, Goldman, So \& Rocholl (2009) find that positive abnormal stock returns accompany nominations of politically connected board members. Brockman et al. (2013) find that in jurisdictions with weak legal systems or high corruption, politically connected bidders outperform unconnected peers. The benefits are not limited to domestic firms. Sojli \& Tham (2017) find that foreign political connections increase firm value and improve access to foreign markets. In a recent study of small- and medium-sized enterprises (SMEs), Qi \& Nguyen (2020) find that politically connected SMEs are more likely to approach banks for loans. Likewise, Khwaja and Mian (2005) find that government banks favor politically connected firms. In previous cases, firms leverage political connections to reduce the political uncertainty they face. Further, Beaulieu et al. (2005) use political news to show that political risk increases stock volatility, suggesting that firms can diversify political risk under certain conditions. 
There is also a large mass of literature studying the factors of lending terms. For example, Bharath et al. (2009) find that repeated borrowing leads to lower lending costs due to the reduction of asymmetries. Custódio et al. (2013) find that firms with higher asymmetric information have lower debt maturities, which might lead to credit and liquidity shocks (Farinha et al., 2019). From a bank's perspective, firm transparency and riskiness are crucial. Hung, Kim \& Li, (2018) show that compared to nonconnected firms, connected firms issue fewer earnings forecasts. Also, Chen et al. (2010) find that politically connected firms are associated with enhanced information asymmetry due to reduced transparency.

Another strand of the literature looks at the effects of regulations on the cost of borrowing. For example, Ioannidou (2005) and Agarwal (2014) point out that supervisory behavior is not homogenous across U.S. regulators and that this might affect the economy in multiple dimensions. More recently, Deli et al. (2019) show that enforcement actions decrease the cost of lending. The authors conjecture that the mechanism at work is that of competition-reputation. ${ }^{3}$

Many authors have devoted great efforts in trying to understand the mechanisms that pin down loan pricing under different heterogeneous environments, such as bank organizational structure, bank competition, and the economic environment under which they operate. Ruckes (2004) argues that credit standards tend to be characterized by large volatility and that the main reason for this is the competition among banks over the business cycle. The author maintains that bank-screening activity is heterogeneous over the business cycle. As a result, this affects bank competition and eventually the quality of borrowers. Particularly, the author argues that during expansions, banks tend to give loans to lower-quality borrowers when there is intense price competition among lenders and lower screening activity. ${ }^{4}$ Canales and Nanda (2012) show that decentralized banks tend to be more responsive under

\footnotetext{
${ }^{3}$ According to the authors, the competition-reputation effect pertains to the fact that punished banks suffer from a lower reputation stigma after enforcement takes place and because they compete with other banks in the syndicated loan market, they offer lower loan costs. Furthermore, Deli et al. (2019), argue that such an outcome has a clear positive welfare outcome for society.

${ }^{4}$ Gomez and Ponce (2014) find that the relationship between bank competition and the quality of loans is U-shaped.
} 
competition and are more likely to increase credit. More recently, Lian (2018) finds a negative relationship between loan spreads and bank competition.

Giambona et al. (2017) show that managers express sentiment via subjective perceptions of the political exposure of their firm. In this work, we utilize political sentiment, which captures good or bad news regarding a firm's exposure to political events. This measure also captures potential manager biases regarding political shocks. We conjecture that more negative exposure to political events (captured via low values of political sentiment) increases the cost of loans.

Hypothesis 1: Firms with lower political sentiment have higher loan costs.

Next, we argue that foreign operations help firms diversify exposure due to political events. The relevant literature, however, tends to be controversial on this issue. On one hand, much of the early literature on MNEs posits a diversification benefit for multinationals, leading to lower risk and higher leverage (e.g., Hughes, Logue \& Sweeny, 1975). On the other hand, more recent studies show that international diversification increases firm risk (Bartov, Bodnar \& Kaul, 1996; Kobrin, 2020). Many studies try to identify factors that affect the relationship between firm risk and international diversification. Kwok \& Reeb (2000), for example, show that the relative risk between host and source country matters.

Although numerous studies examine channels through which firms diversify risk, few, if any, directly examine the mechanism under which international diversification mitigates the negative effect of exposure due to political events on the cost of loans. Beaulieu et al. (2005) utilize political news regarding Quebec's separation from the Canadian federation to proxy for political risk. They find enhanced stock volatility for firms exposed to political risk, though investors do not seem to require higher premia. Diversification can indirectly explain the latter. Disentangling the effect of foreign operations on the relationship between political sentiment and loan costs, we state our hypothesis as follows: 
Hypothesis 2a: The negative effect of lower political sentiment on the cost of loans for MNEs decreases when the number of countries in which an MNE has subsidiaries increases.

Hypothesis 2b: The negative effect of lower political sentiment on the cost of loans for MNEs decreases when the number of foreign subsidiaries increases.

Next, we want to examine whether there is any "pattern" in the choice of foreign subsidiaries that drive the international diversification of negative exposure to political events. The international finance literature suggests that international diversification is beneficial only if it takes place in the firm's core business (Doukas \& Lang, 2003). Further, Van Zanten \& Van Tulder (2018) add that MNEs protect their sustainable development by taking action within their operations. Following this strand of literature, we examine whether international diversification via subsidiaries in the same industry (i.e., in the core business) reduces the impact of the political sentiment on the cost of loans. Our hypothesis is the following:

Hypothesis 2c: The negative effect of lower political sentiment on the cost of loans for MNEs decreases when the ratio of foreign subsidiaries in the same industry increases.

Finally, exploring certain strategic choices that potentially drive the international diversification of firm-level (negative) political exposure we consider the political conditions in the subsidiaries' countries. The international finance literature recognizes that a country's political situation affects MNE success (see e.g., Boubakri et al., 2013; Brockman et al. 2013; Sojli \& Tham, 2017). Brown et al. (2011) provide theoretical reasons from the political science literature for why higher political polarization decreases political corruption. They confirm their hypothesis using a multi country data set. If higher political polarization decreases political corruption, we expect that MNEs with relatively 
more subsidiaries in such countries to benefit. As such, banks will perceive these MNEs as more creditworthy. We formalize this in the following hypothesis:

Hypothesis 2d: The negative effect of lower political sentiment on the cost of loans for MNEs decreases when the ratio of foreign subsidiaries in countries with higher polarization increases.

\section{Empirical specification}

We use ordinary least squares to estimate the following model:

$$
\begin{aligned}
\operatorname{SPREAD}_{f, b, t}= & \beta_{o}+\beta_{1} \cdot \text { PSentiment }_{f, t-1}+\beta_{2} \cdot L_{l, t}+\beta_{3} \cdot B_{b, t}+\beta_{4} \cdot F_{f, t-1}+\mu_{b}+v_{t} \\
& +\xi_{S I C}+\epsilon_{f, b, t}
\end{aligned}
$$

In eq. (1), $S P R E A D$ is the spread over LIBOR on the drawn amount plus the facility fee in basis points for loans from bank $b$ to firm $f$ in year $t$. PSentiment is the measure of political sentiment in firm $f$ at time $(t-1)$. This measure is from Hassan et al. (2019) and it captures good or bad news regarding a firm's exposure to political events. In line with previous studies (e.g., Ivashina \& Scharfstein, 2010; Delis et al., 2019) we control for loan $(L)$, firm $(F)$, and bank $(B)$ characteristics to rule out alternative explanations. In addition, in our models, we include bank, year, sector — using three-digit SIC codes — as well as loan purpose and loan-type fixed effects.

We control for several loan characteristics that potentially affect the cost of lending. Namely, we control for loan duration using a dummy that equals 1 if a bank and a firm have a relationship in the previous five years (Bharath et al., 2009). We use a dummy that equals 1 if the loan has financial covenants to control for unobserved borrower-specific risk factors (e.g., Carey and Nini, 2007; Karavitis et al., 2019). Regarding bank-specific characteristics, we control for bank size using the natural logarithm of total assets.

In addition, we utilize several firm-level variables to control for firm characteristics. The relevant literature finds that firm size matters (e.g., Almeida \& Campelo, 2010). We control for firm 
size using the natural logarithm of total assets. Moreover, we control for firm profitability and marketto-book ratio, as these measures depict a firm's ability to service its debt obligations (e.g., Guntay \& Hackbarth, 2010). To control for potential alternative sources for funding, we also use NYSE, which equals 1 if a firm is listed on the New York Stock Exchange. We expect that firms with access to public markets might benefit from lower interest rates.

\subsection{Measuring firm-level political sentiment}

Several studies use natural language processing techniques from various sources, such as newspapers or corporate documents (e.g., 10-K filings). They aim to derive important insights about firms (e.g., Baker et al., 2016, Loughran \& McDonald, 2011). These studies use predefined dictionaries of specific words to draw inferences about certain categories, such as firm risk, using advanced natural language processing techniques. Hassan et al. (2019) utilize information from earnings conference calls to capture political uncertainty at the firm level. The authors gather around 180,000 conference calls for more than 7,000 listed U.S. firms for 2002 to 2016. Because earnings conference calls usually occur once per quarter, the authors provide a dynamic, quarterly measure of firm-level political uncertainty. Hassan et al. (2019) differs from previous studies in that the authors endogenously capture a series of words that are relevant to a specific topic. Because of this, their database consists of several components that capture either risk or sentiment.

The authors employ advanced methods developed in computational linguistics (e.g., Manning et al., 2008) and create training libraries that categorize text as political or nonpolitical. Through this procedure, they identify bigrams — two-word combinations - mostly utilized in political talk. They construct their political sentiment index by combining bigrams with positive and negative words these words are similar to the list in Loughran \& McDonald (2011). In mathematical terms, they calculate the political sentiment measure in the following manner:

$$
\text { PSentiment }_{i, t}=\frac{1}{B_{i, t}} \sum_{b}^{B_{i, t}}\left(1[b \in \mathbb{P} \backslash \mathbb{N}] \times \frac{f_{b, \mathbb{P}}}{B_{\mathbb{P}}} \times \sum_{c=b-10}^{b+10} S(c)\right) .
$$


In the formula, $b$ denotes a transcript for firm $i$ in quarter $t$; specifically, we set $b=1, \ldots, B_{i t}$. In addition, $\mathbb{P}$ is a library containing political topics, and $\mathbb{N}$ a library not containing political topics. Hence, $\mathbb{P} \backslash \mathbb{N}$ is a set of bigrams in the political library but not in the nonpolitical one. Moreover, $c$ denotes a bigram, and $S(c)$ equals +1 when a specific bigram is associated with positive sentiment, -1 if the sentiment is negative, and zero otherwise. Further, $f_{b, \mathbb{P}}$ indicates the frequency of a specific bigram. Finally, $1[b \in \mathbb{P} \backslash \mathbb{N}] \times \frac{f_{b, \mathbb{P}}}{B_{\mathbb{P}}}$ is the inverse document frequency multiplied by term frequency. Higher values of the political sentiment index indicate the presence of more positive words than negative words. For example, a firm with high positive values of the index might have been affected beneficially by new legislation, while a firm with low values might have been hit by antitrust action.

The authors perform several scrutiny tests to make sure their index captures political sentiment. Importantly, their measure is dynamic and changes within firms over time; it takes higher values around important political events and presents heterogeneities in different sectors. The correlation of their firmlevel index with the well-perceived and highly cited aggregate measure of political uncertainty developed by Baker et al. (2016) is highly positive, further validating their work. Finally, the authors look at how their index affects firm outcomes and find, inter alia, that higher political uncertainty predicts higher stock volatility, along with lower investment and employment growth.

\subsection{Empirical identification}

Our research design and the granularity of our dataset (i.e., loan level) enable us to mitigate endogeneity concerns. First, we utilize not only firm-level characteristics (to control for demand-side effects) as in Anderson et al. (2004), but also, we use bank controls to check for potential supply-side effects. Second, to ensure that the choice of regressors does not drive our results, we run several different specifications utilizing additional controls.

Third, even though we control for numerous firm-, bank-, and loan-level characteristics, the empirical identification of the causal effect running from the firm's political sentiment to the cost of 
borrowing ( SPREAD) is still challenging. To rule out alternative explanations stemming from confounders, we utilize various fixed effects. The multilevel structure of our dataset enables us to use time-invariant as well as time-varying fixed effects to mitigate omitted-variable bias. Bank and industry fixed effects (at the three-digit SIC level) control for time-invariant characteristics of financial intermediaries and sectors, but time fixed effects capture annual common shocks.

An issue with the main variable of interest — political sentiment — is that it might be endogenous, either because during conference calls the interviewees purposely use specific language that does not describe the reality of the firm, or because our model might suffer from omitted variables. Not having a quasi-experiment at hand to provide a bias-free estimate of how political sentiment affects the cost of lending, we rely on an instrumental variables approach.

Our strategy relies on an instrument from the International Country Risk Guide (ICRG) database, specifically External conflict. This variable assesses the risk an incumbent government faces from both internal and external pressures (also see Henisz et al., 2010; Darenteli \& Hill, 2016). Higher values indicate better standing regarding external conflicts. We expect that parent firms with subsidiaries in countries with better standing regarding external conflict have more positive political sentiment - a lesser exposure to political events, on average. Using the Orbis database, we locate the subsidiaries of U.S. firms. We then match the countries of the U.S. subsidiaries with the countries in the ICRG database and construct a weighted value for External conflict. We do this because the presence of U.S. multinationals is heterogeneous around the world, and some firms have a larger presence in some countries than others. Thus, the effect of External conflict will be higher in countries where a parent company is more active. ${ }^{5}$

A potential issue is that external conflict might affect the political sentiment of the parent company and its loan cost. This can happen when a syndicate has disproportionately more banks from countries with higher external conflict. If that is the case, these banks could pass the cost of higher

\footnotetext{
${ }^{5}$ The value of the weighted external conflict changes for each parent company each year, as the country values from ICRG are updated annually.
} 
uncertainty to their borrowers. This would render our identification invalid. We argue, however, that this is not true in our sample. According to Kim (2019) almost 70\% of banks in a syndicate are from the country in which a firm has its headquarters - in our case the United States. In addition, the way we construct our instrument (taking weighted average values) would tackle that problem.

\section{Data and summary statistics}

\subsection{Data}

This study uses several databases. From Thomson Reuters LPC (Dealscan), we identify the cost of syndicated loans and other important loan characteristics. We complement these data with bank financial information hand-collected from Call Reports from the Federal Reserve Board of Governors (FRB). Firm-level information is from Compustat. In addition, we use Orbis to identify each firm's ownership information. It is via the Orbis database that we identify each MNE's foreign subsidiaries and execute our analysis utilizing parent firms' foreign operations. This allows us to use an instrumental variables approach.

The sample selection from Dealscan follows Karavitis et al. (2020), who use insights from Lim et al. (2014). This is because potential bias might arise if the sample is not selected carefully. ${ }^{6}$ Importantly, we carefully hand-match each lender from Dealscan with its commercial bank identifier (i.e., RSSD9001) from Call Reports. This is crucial because it allows for the use of bank fixed effects. We merge Dealscan with Compustat using the updated links from Chava and Roberts (2008).

Our analysis is at the loan-facility level. According to Deli et al. (2019) this is more appropriate than analysis at the package level because loan facilities may differ in several dimensions, such as the starting date or loan type, among others. The use of loan packages, by simply adding facilities without accounting for their differences, may lead to biased estimates. Our baseline estimation has 35,951

\footnotetext{
${ }^{6}$ Karavitis et al. (2020) state that it is essential to disentangle banks from nonbanks. Examples of nonbank institutions are mutual funds or insurance companies.
} 
observations. We count 8,128 unique facilities and 1,927 unique firms. The number of unique banks is 361.

Finally, to explore in detail how foreign operations affect the relationship between political risk and the cost of lending, we utilize ownership information from the Orbis database. We link each U.S. borrower in our dataset with its respective subsidiaries globally. Based on the above, we can pin down the number of different countries in which an MNE operates, along with the number of foreign subsidiaries it owns.

Our database spans from 2002 to 2015 . The upper limit is to match the time-series availability of all data sources in this analysis. As is standard in the literature, we winsorize all continuous variables (except the dependent variable) at the $1 \%$ and $99 \%$ levels. Concise information is in appendix table A1.

\subsection{Summary statistics}

We present summary statistics in Table 1 and correlations for some of the variables in Table A2. All-indrawn (AISD), which is the main dependent variable in our analysis, has a mean value of 152 basis points. The total cost of borrowing $(T C B)$, has a mean value of 110 basis points. These values are close to those in the literature on syndicated loans (e.g., Berg et al., 2016). More than $50 \%$ of firms have prior relationships with a syndicate bank (as Relationship dummy shows). Furthermore, about 53\% of syndicated loans require a covenant.

We start by presenting summary information about the main explanatory variable, Political sentiment, which has a zero mean and standard deviation of 1 . This is expected, as we have standardized these variables to match the procedure in Hassan et al. (2019). We find that about $80 \%$ of the firms in our sample trade on the New York Stock Exchange (NYSE), indicating that most firms in our sample are public. Further, the average number of foreign countries in which an MNE operates is around 7.5, the number of subsidiaries in foreign countries is around 17, and the number of subsidiaries in low-tax countries is about 16.5 .

\section{[Insert Table 1 about here]}




\section{Results}

\subsection{Preliminary results}

Table 2 presents our preliminary findings. It shows the effect of political sentiment on the cost of syndicated loans $(A I S D)$. Apart from the main control variables, we start gradually adding fixed effects. Column (5) is the most conservative case in this table, where we include bank, year, sector (three-digit SIC), purpose-, and loan- type-fixed effects. We find that higher Political sentiment - that is, more positive political sentiment for a firm - leads to a decrease in loan cost. According to the most restrictive specification in column (5), the coefficient of Political sentiment is negative and highly statistically significant at the $1 \%$ level (coefficient: -4.14 and $t$-statistic: -10.45 ).

Our findings are in accordance with the mechanisms in the relevant literature (Bradley et al., 2016; Kim, 2019). Specifically, if a lender believes a firm will face higher uncertainty and thus have problems repaying debt, it might opt out of a loan contract or charge a premium for the higher uncertainty.

\section{[Insert Table 2 about here]}

Bae and Goyal (2009) document that poor contract enforceability leads to worse loan terms. The idea behind this is that banks trust more firms who [they] know will be more likely to pay back their debt. Thus, one could argue that the effect of political sentiment in the cost of lending is spurious and that it captures the effect of a firm's governance characteristics. To verify that our results withstand the inclusion of governance characteristics we include several controls that the past literature has found to be significant in determining loan outcomes. Specifically, we expect that better governancemanifested in the form of a larger board size or audit committee size, will decrease the cost of lending (Anderson et al., 2004). We present our results in Table 3 that follow next.

\section{[Insert Table 3 about here]}

Next, we check whether our preliminary results hold when we exclude facilities where the lead arranger is a top 3 bank. The argument here is that the role of leading banks might be crucial and that these banks differ from the rest in a way that our model is unable to capture. This could add bias in our 
findings. We present results of this exercise in Table 4. If anything, our findings are qualitatively the same and even stronger in statistical terms.

\section{[Insert Table 4 about here]}

Another concern is that our variable of interest might be picking up firm credibility and thus the result we find is not purely due to political uncertainty. To deal with this concern, we include company ratings. Higher values of this variable indicate a lower rating. The results in Table 5 show, as expected, that firms with lower ratings pay higher premiums for loans. Paramount for our analysis is that political sentiment still enters with the expected sign and it is strongly statistically significant at the $1 \%$ level.

\section{[Insert Table 5 about here]}

Although we include bank, sector, year, primary purpose, and loan-type fixed effects, one concern is that omitted variables that change in time, but not included in our analysis, might potentially drive our results. To deal with this issue we re-run models of the preliminary setting by including bank-year, SIC3-year, loan-type-year, and purpose-year fixed effects, where necessary. The results of this test are in table 6 . We find our results to be robust in all these cases.

\section{[Insert Table 6 about here]}

Our next exercise is to look at how the effect of political sentiment differs across different industries. To this end, we define the following main industries: (i) mining, (ii) construction, (iii) manufacturing, (iv) transport, (v) wholesale, (vi) retail, (vii) finance, and (viii) services and perform our analysis in each category. Our results in Table 7 indicate that the effect of political uncertainty is higher in mining, manufacturing, and transport. We find no effect in other industries, although we would like to point that in some industries our sample is small, and the inclusion of many fixed effects might soak up the effect.

\section{[Insert Table 7 about here]}

\subsection{Firms'foreign operations}

Our next step is to explore how firms' foreign operations affect the potency of political shocks on the cost of loans. To perform this analysis, we match the U.S. firms in our sample with their foreign 
subsidiaries using the Orbis database. Our granular data allow us to examine how political sentiment affects the cost of loans when firms operate (or do not operate) in foreign countries. Our premise is that MNEs diversify via foreign operations and thus mitigate the negative effects of low political sentiment using their large networks of foreign subsidiaries.

Ex ante it is not clear whether foreign operations increase or decrease the impact of political sentiment on the cost of loans. The empirical evidence regarding MNEs' benefits from international diversification is unclear (see e.g., Bartov, Bodnar \& Kaul, 1996; Hughes, Logue \& Sweeny, 1975; Kwok \& Reeb, 2000; Doukas \& Lang, 2003). On one hand, firms with an international presence are exposed to foreign risk, but at the same time they can achieve higher diversification. To examine how foreign operations affect the cost of lending via political sentiment, we employ four variables: (i) the number of foreign countries in which a multinational firm has a presence, (ii) the number of foreign subsidiaries of a firm, (iii) the percentage of foreign subsidiaries in the same industry, and (iv) the degree of political polarization of the subsidiaries' countries. These variables serve a dual purpose. First, they proxy for any potential risk a multinational firm might face by operating in foreign countries. Second, they capture potential incentives of tax avoidance, which affects the cost of loans (see e.g., Hasan et al., 2014).

We present our results in table 8 . In line with our findings in table 2 and throughout all specifications, PSentiment enters with a negative and strongly significant sign. In this table, the variable of interest is the interaction term between Political sentiment and the proxies for foreign operations. Column (1) shows the value of the interaction term between political sentiment and the number of countries in which a multinational operates. Its value is positive and statistically significant at the $1 \%$ level. This indicates that for firms with international operations, the potency of political sentiment is smaller. For example, firms with low values of Political sentiment can offset the negative effect on its loan cost, by having at least subsidiaries in 12 different countries. ${ }^{7}$ Column (2) shows how PSentiment fares when interacted with the number of foreign subsidiaries. Again, the interaction term is positive

\footnotetext{
${ }^{7}$ We calculate this by taking the ratio: $-\frac{\text { coeff(PSentiment) }}{\text { coeff (Interaction) }}$.
} 
and statistically significant (coeff. 0.156 and $t$-stat: 3.82 ). In the same manner, we calculate the number of subsidiaries a firm needs to offset the negative effects of low PSentiment; this translates to about 37 subsidiaries (5.772/0.156).

Thus far, our findings indicate that a firm's foreign operations mitigate the negative effects of low Political sentiment on the cost of loans. Using a firm-level measure that accounts for the mean effect of political exposure and current networks of foreign subsidiaries, we provide evidence regarding MNEs' abilities for international diversification. This finding is in line with earlier studies (e.g., Beaulieu et al., 2005). In turn, we decompose some of these factors.

First, this finding not only highlights the international diversification of political shocks, but it also considers — at least indirectly — tax-planning activities available to MNEs as a factor that reduces the impact of low political sentiment on the cost of loans. The latter extends and complements the significant contribution of Hasan et al. (2014). The authors, using single-country data, show that banks penalize aggressive tax avoidance among U.S. firms because it increases the risk banks bear. Our study differs from Hasan et al. (2014) in that we use the Orbis database to pin down exactly how many different countries an MNE is operating in and how many foreign subsidiaries it has. In this way, we explore cross-country heterogeneity and provide robust new evidence about how banks anticipate their customers' cross-country tax-avoidance opportunities. In untabulated tests, we also experiment with the percent of low tax subsidiaries for each MNE in our sample. The results are qualitatively similar to those in columns 1 and 2 and are available upon request.

Next, we examine whether economies of scale through foreign operations help MNEs diversify their political exposure. To this end, we use the interaction of PSentiment with the percentage of foreign subsidiaries in the same industry as the parent firm (Foreign Economies of Scale). Column (3) shows the results of this test. The coefficient of (PSentiment $\times$ Foreign Economies of Scale) is positive and significant at the $1 \%$ level. This finding is in line with Doukas \& Lang (2003), who document that international diversification is beneficial only if it takes place in a firm's core business. When an MNE 
invests in firms in the same industry, it employs economies of scale, which benefits the MNE and mitigates bad news due to exposure to political events.

Finally, in column (4) we examine whether political environments in subsidiaries' countries mitigate the effects of low political sentiment on the cost of loans. The coefficient of (PSentiment $\times$ Sub. Country Political Polarization) is once again positive and significant at the $1 \%$ level, suggesting that diversification toward subsidiaries in countries with high political polarization reduces the cost of lending due to lower corruption, as Brown et al. (2011) suggests.

\section{[Insert Table 8 about here]}

For our core specification presented in Table 8, we perform two additional exercises. First, apart from political sentiment (PSentiment), we also control for political risk (PRisk). This is because one might argue that our main variable, political sentiment, picks up the effect of political risk. This is not possible as the two variables are weakly correlated (in our sample their correlation is about -0.07) and Hassan et al. (2019) are clear in that while political sentiment captures the mean of political shocks, political risk captures the variance. Second, in our rich model that includes a plethora of fixed effects that are standard in the literature of syndicated loans, we also add firm fixed effects to rule out any possibility that our findings are driven by time-invariable factors at the firm level that are unobservable. Results in table A3 and table A4 indicate that our findings are robust with the inclusion of additional variables and firm fixed effects. ${ }^{8}$

In a similar manner to what was described above (Tables 3 to 5), we present a series of sensitivity tests regarding firms' foreign operations. Specifically, we control for governance (Table 9), we check whether our results hold when we drop observations where the lead arranger is a top 3 bank (Table 10), and we control for credit rating (Table 11). In all cases our hypotheses stand.

\section{[Insert Table 9, $10 \& 11$ about here]}

\footnotetext{
${ }^{8}$ The use of firm fixed effects on top of the fixed effects we already include might lead to some of the main controls regarding firms' foreign operations to drop in the regression process. This is because firm-fixed over-saturate our model. Because this paper aims to study the moderating effects of foreign operations in syndicate loan lending costs due to negative political exposure, we have opted not to use firm fixed effects in most of our tables. Nonetheless, the models presented in this paper still provide statistically strong results of our main findings even with the inclusion of firm fixed effects. To conserve space, we have not included these tables herein, but they are available upon request.
} 
One could argue that the effect we obtain might not be precise, as we have not accounted for firmlevel uncertainty shocks. Among others, Alfaro et al. (2018) show that higher uncertainty decreases investment, hiring, and affects firms' financial policies. Alfaro et al. (2018) create measures of firmlevel volatility, which broadly capture firms' exposure and are estimated based on a Bartik identification strategy that exploits the exposure of different regions to different types of industry level shocks. Importantly here, this aggregate uncertainty differs among firms (e.g., energy companies are affected more due to oil shocks). Since firms are affected by such shocks, it is possible that financial intermediaries perceive higher firm volatility as a factor that makes firms less likely to pay their debt. Because of this, we expect financial intermediaries to provide worse loan terms for more volatile firms.

We test this using controls of realized and implied volatility using the Alfaro et al. (2018) measures of volatility. Our results in Table 12 and Table 13 show that firm volatility indeed plays a key role; both realized and implied volatility enter with a positive and highly significant coefficient, indicating that firm volatility is priced in the loan market. The inclusion of firm volatility, however, does not affect markedly our variables of interest. The interaction terms are still statistically significant and in tandem with our hypotheses.

\section{[Insert Table $12 \& 13$ about here]}

\subsection{Results with instrumental variables}

So far, the results document an association between political sentiment and the cost of lending. However, due to omitted variables or measurement errors, our findings might be biased and thus not capture the pure effect of political sentiment on the cost of lending, even with the utilization of fixed effects. Considering that we do not have a purely natural exogenous shock to assist in the identification, we resort to a two-stage least squares approach (2SLS) to mitigate potential bias errors.

The model for the 2SLS model is the following:

$$
\begin{aligned}
\operatorname{SPREAD}_{f, b, t}= & \beta_{o}+\beta_{1} \cdot \text { PSe }_{\text {nttment }}{ }_{f, t-1}+\beta_{2} \cdot L_{l, t}+\beta_{3} \cdot B_{b, t}+\beta_{4} \cdot F_{f, t-1}+\mu_{b}+v_{t}+\xi_{\text {SIC }} \\
& +\epsilon_{f, b, t}
\end{aligned}
$$




$$
\text { PSentiment }_{f, t-1}=\gamma_{o}+\gamma_{1} \cdot I V+\gamma_{2} \cdot L_{l, t}+\gamma_{3} \cdot B_{b, t}+\gamma_{4} \cdot F_{f, t-1}+\mu_{b}+v_{t}+\xi_{S I C}+u_{f, b, t}
$$

We use two potential IVs in our analysis. First, motivated by the international finance literature, we look at how external conflict adds to the broad uncertainty of an MNE (see e.g., Henisz et al., 2010; Darenteli \& Hill, 2016). Thus, we use external conflict as a potential instrument. We construct this instrument based on the location of U.S. MNEs from Orbis. With this at hand, we employ information from the International Country Risk Guide (ICRG) database. Specifically, for each parent company we construct an annual weighted average based on the ICRG component External conflict. ${ }^{9}$ (For example, a parent company that has four subsidiaries in three different countries with external conflict values of: 2, 5 (twice), and 3 for the year 2006 would have an weighted average value of external conflict for that year equal to: $\frac{1}{4} \times 2+\frac{2}{4} \times 5+\frac{1}{4} \times 3=3.75$.) Higher values of External conflict indicate better outcomes for a country (i.e., the risk of external conflict is less pronounced). We expect that a parent company with subsidiaries in countries with lower external conflict have a higher political sentiment domestically. In addition, this instrument is valid because it affects the cost of loans only via the political sentiment of the parent company (i.e., the way managers anticipate the political risk of their firm). If external conflict affects banks within a syndicate directly, this might render our identification invalid. However, this cannot be the case, as most banks in the syndicate are from the same country ( $70 \%$ according to Kim, 2019), but the subsidiaries, from which we construct the instrument, are in foreign countries.

The second instrument is the average five-year lagged value of the political sentiment index measured at the three digits SIC level. We expect that sectors with more positive political sentiment will continue to do so in the future. However, our premise is that these deep lags at the sectoral level, will not affect banks' decisions about the terms of lending of a specific firm five years in the future.

\footnotetext{
${ }^{9}$ When calculating the average value of external conflict, we give higher weight to values from the countries in which a parent company has more subsidiaries.
} 
That is, the lagged values of political sentiment at the sectoral level affect the cost of loans only through a firm's political sentiment at present.

We present our results in table 14. Even-numbered columns show the first-stage results, and oddnumbered columns show the second-stage results. Our findings are in accordance with our conjecture. Specifically, the instrument has a positive and statistically significant coefficient in the first stage. This means that lower external conflict and the lagged value of political sentiment at the sector level exert a positive effect on firm political sentiment. When observing the second-stage results, the coefficient of Political sentiment is negative and statistically significant but is higher (in absolute terms) than the baseline model. This could indicate an underestimation of the effect if endogeneity concerns are not considered. In all cases, the first-stage $F$-statistics are far higher than the Stock and Yogo (2002) critical values, reassuring our findings..$^{10}$

\section{[Insert Table 14 about here]}

\subsection{Additional tests}

Our final sensitivity test is to look at how political sentiment affects the total cost of lending instead of the all-in-spread-drawn (AISD). It is important to test whether our results are robust to the use of such a measure, as private loan contracts have complex pricing mechanisms, and relying only on one statistic (AISD) might not capture the whole effect. After gathering all necessary information from Dealscan and Compustat and following the process in Berg et al. (2016), we calculate the total cost of borrowing. We then rerun all models in the main text and succinctly provide the results in table 15 . In this table, each row is a regression. Our results are very close to our initial findings, adding further confidence in our conclusions.

\section{[Insert Tables 15 about here]}

\footnotetext{
${ }^{10}$ The higher magnitude of the effect of political sentiment on the cost of lending could be due to the presence of compliers. That is, the IV captures a local average treatment effect (LATE) instead of the population. This issue is well known in the empirical literature (see e.g., Jiang, 2017).
} 


\section{Conclusion}

This paper studies how firm-level political sentiment affects the cost of syndicated loans of multinational enterprises. We conjecture that increases in positive political sentiment (as indicated by higher values of the political sentiment index) decrease the cost of syndicated loans. Our results confirm this conjecture, as the coefficient is negative and strongly statistically significant in most tests. The mechanism at work operates along the following lines: firms with higher political sentiment face lower political exposure. Banks use this information to price properly the syndicated loan contract. Next, we show that the foreign operations of parent companies (MNEs) play an important role, as they can be a diversification force. Through this international diversification, MNEs can decrease (or even eliminate) the negative effects of political exposure on their cost of loans. Our results further suggest that MNEs with foreign subsidiaries in the same industry, and in countries with higher political polarization can mitigate the negative effects of low political sentiment on the cost of loans. Finally, using the international network of MNE subsidiaries, we construct a new firm-level political exposure proxy and we devise an instrumental-variables estimation to obtain unbiased estimates of how political exposure affects the cost of loans. Our results remain strong in all these tests.

Our results have implications for business practices in a global setting. Understanding the way firm-level political exposure affects the cost of lending for MNEs should be of interest to domestic and international investors. Moreover, the channels through foreign operations that an MNE can use to diversify its political exposure should be of interest to MNEs that seek international partners. 


\section{References}

Agarwal, S., Lucca, D., Seru, A., \& Trebbi, F. (2014). Inconsistent regulators: Evidence from banking. The Quarterly Journal of Economics, 129(2), 889-938.

Alfaro, I., Bloom, N., \& Lin, X. (2018). The finance uncertainty multiplier (No. w24571). National Bureau of Economic Research.

Almeida, H., Campello, M. (2010). Financing frictions and the substitution between internal and external funds. Journal of Financial and Quantitative Analysis 45, 589-622.

Anderson, R., Mansi, S. \& Reeb, D. (2004). Board characteristics, accounting report integrity, and the cost of debt. Journal of Accounting and Economics 37, 315-342.

Ansolabehere, S., de Figueiredo, J. M. \& Snyder, J. M. (2003). Why is there so little money in U.S. politics? Journal of Economic Perspectives 17(1), 105-30.

Bae, K. H., \& Goyal, V. K. (2009). Creditor rights, enforcement, and bank loans. The Journal of Finance, 64(2), 823-860.

Baker, S. R., Bloom, N. \& Davis, S. J. (2016). Measuring economic policy uncertainty. Quarterly Journal of Economics 131(4), 1593-1636.

Bartov, E., Bodnar, G., Kaul, A. (1996). Exchange rate variability and the riskiness of U.S. multinational firms: Evidence from the breakdown of the Bretton Woods system. Journal of Financial Economics 42(1), 105-132.

Beaulieu, M., Cosset, J. \& Essaddam, N. (2005). The impact of political risk on the volatility of stock returns: The case of Canada. Journal of International Business Studies 36, 701-718.

Berg, T., Saunders, A. \& Steffen, S. (2016). The total cost of corporate borrowing in the loan market: Don't ignore the fees. The Journal of Finance 71(3), 1357-1392.

Bertrand, M., Bombardini, M. \& Trebbi, F. (2014). Is it whom you know or what you know? An empirical assessment of the lobbying process. American Economic Review 104, 3885-3920.

Bertrand, M., Bombardini, M., Fisman, R. \& Trebbi, F. (2020). Tax-exempt lobbying: Corporate philanthropy as a tool for political influence. American Economic Review 110(7), 2065-2102.

Bharath, S. T., Dahiya, S., Saunders, A., Srinivasan, A. (2009). Lending relationships and loan contract terms. The Review of Financial Studies 24(4), 1141-1203.

Boubakri, N., Mansi, S. A. \& Saffar, W. 2013. Political institutions, connectedness, and corporate risktaking. Journal of International Business Studies, 44(3): 195-215.

Bradley, D., Pantzalis, C. \& Yuan, X. (2016). Policy risk, corporate political strategies, and the cost of debt. Journal of Corporate Finance 40, 254-275.

Brockman, P., Rui, O. M. \& Zou, H. (2013). Institutions and the performance of politically connected M\&As. Journal of International Business Studies, 44(8), 833-852.

Brown, D., Touchton, M. \& Whitford, A. (2011). Political polarization as a constraint on corruption: A cross-national comparison. World Development 39, 1516-1529.

Brühne, A. \& Jacob, M. (2019). Corporate tax avoidance and the real effects of taxation: A review. Available at: SSRN: or http://dx.doi.org/10.2139/ssrn.3495496.

Canales, R., \& Nanda, R. (2012). A darker side to decentralized banks: Market power and credit rationing in SME lending. Journal of Financial Economics, 105(2), 353-366.

Carey, M., Nini, G. (2007). Is the corporate loan market globally integrated? A pricing puzzle, The Journal of Finance 62(6), 2969-3007.

Chava, S. \& Roberts, M. R. (2008). How does financing impact investment? The role of debt covenants. The Journal of Finance, 63(5), 2085-2121.

Chen, C. J., Ding, Y. \& Kim, C. F. (2010). High-level politically connected firms, corruption, and analyst forecast accuracy around the world. Journal of International Business Studies, 41(9), $1505-1524$.

Cruz, C., Keefer, P. \& Scartascini, C. (2016). Database of Political Institutions 2015: Codebook. Washington, DC: Inter-American Development Bank.

Custódio, C., Ferreira, M. A. \& Laureano, L. (2013). Why are U.S. firms using more short-term debt? Journal of Financial Economics, 108(1), 182-212. 
Darendeli, I. S. \& Hill, T. (2016). Uncovering the complex relationships between political risk and MNE firm legitimacy: Insights from Libya. Journal of International Business Studies, 47, 6892.

Deli, Y. D., Delis, M. D., Hasan, I. \& Liu, L. (2019). Enforcement of banking regulation and the cost of borrowing. Journal of Banking \& Finance, 101, 147-160.

Delis, M., Hasan, I., Ongena, S. (2019). Democracy and credit. Journal of Financial Economics (In press).

Doukas, J., Lang, L. (2003). Foreign direct investment, diversification and firm performance. Journal of International Business Studies 34, 153-172.

Faccio, M., Masulis, R. W. \& McConnell, J. J. (2006). Political connections and corporate bailouts. The Journal of Finance, 61(6), 2597-2635.

Farinha, L., Spaliara, M. E. \& Tsoukas, S. (2019). Bank shocks and firm performance: New evidence from the sovereign debt crisis. Journal of Financial Intermediation, 40, 100818.

Gad, M., Nikolaev, V. V., Tahoun, A. \& van Lent, L. (2019). Firm-level political risk and credit markets. Available at SSRN 3395266.

Giambona, E., Graham, J. \& Harvey, C. (2017). The management of political risk. Journal of International Business Studies, 48, 523-533.

Goldman, E., Rocholl, J. \& So, J. (2009). Do politically connected boards affect firm value? The Review of Financial Studies, 22(6), 2331-2360.

Gomez, F., \& Ponce, J. (2014). Bank competition and loan quality. Journal of Financial Services Research, 46(3), 215-233.

Guntay, L. Hackbarth, D. (2010). Corporate bond credit spreads and forecast dispersion. Journal of Banking and Finance 34, 2328-2345.

Hasan, I., Hoi, C. K. S., Wu, Q. \& Zhang, H. (2014). Beauty is in the eye of the beholder: The effect of corporate tax avoidance on the cost of bank loans. Journal of Financial Economics, 113(1), 109130.

Hassan, T. A., Hollander, S., van Lent, L. \& Tahoun, A. (2019). Firm-level political risk: Measurement and effects. The Quarterly Journal of Economics, 134(4), 2135-2202.

Henisz, W. J., Mansfield, E. D. \& Von Glinow, M. A. 2010. Conflict, security, and political risk: International business in challenging times. Journal of International Business Studies, 41(5), 759-764.

Hughes, L., Logue, D. \& Sweeney, R. (1975). Corporate international diversification and market assigned measures of risk and diversification. Journal of Financial and Quantitative Analysis $10,627-637$.

Hung, M., Kim, Y. \& Li, S. (2018). Political connections and voluntary disclosure: Evidence from around the world. Journal of International Business Studies 49, 272-302.

Ioannidou, V. P. (2005). Does monetary policy affect the central bank's role in bank supervision?. Journal of Financial Intermediation, 14(1), 58-85.

International Country Risk Guide (ICRG) Researchers, 2013, International Country Risk Guide (ICRG) Researchers Dataset, https://doi.org/10.7910/DVN/4YHTPU, Harvard Dataverse.

Ivashina, V., Scharfstein, D. (2010). Bank lending during the financial crisis of 2008. Journal of Financial Economics 97(3), 319-338.

Jiang, W. (2017). Have instrumental variables brought us closer to the truth. The Review of Corporate Finance Studies, 6(2), 127-140.

Jiang, F., Lee, J., Martin, X., Zhou, G. (2019). Manager sentiment and stock returns. Journal of Financial Economics, 132(1), 126-149.

Julio, B. \& Yook, Y. (2012). Political uncertainty and corporate investment cycles. The Journal of Finance, 67, 45-83.

Karavitis, P., Kokas, S., Tsoukas, S. (2020). Gender board diversity and the cost of bank loans, Journal of Corporate Finance (forthcoming). 
Kim, O. S. (2019). Does political uncertainty increase external financing costs? Measuring the electoral premium in syndicated lending. Journal of Financial and Quantitative Analysis, 54(5), 21412178.

Khwaja, A. I. \& Mian, A. (2005). Do lenders favor politically connected firms? Rent provision in an emerging financial market. The Quarterly Journal of Economics, 120(4), 1371-1411.

Kobrin, S. (2020). How globalization became a thing that goes bump in the night. Journal of International Business Policy 3, 280-286.

Kwok, C. \& Reeb, D. (2000). Internationalization and firm risk: An upstream-downstream hypothesis. Journal of International Business Studies 31, 611-629.

Lian, Y. (2018). Bank competition and the cost of bank loans. Review of Quantitative Finance and Accounting, 51(1), 253-282.

Lim, J., Minton, B. A. \& Weisbach, M. S. (2014). Syndicated loan spreads and the composition of the syndicate. Journal of Financial Economics, 111(1), 45-69.

Loughran, T. \& McDonald, B. (2011). When is a liability not a liability? Textual analysis, dictionaries, and 10-Ks. The Journal of Finance, 66(1), 35-65.

Manning, C. D., Raghavan, P. \& Schütze, H. (2008). Introduction to information retrieval. Cambridge University Press.

Pérez-Martín, A., Pérez-Torregrosa, A. \& Vaca, M. (2018). Big Data techniques to measure credit banking risk in home equity loans. Journal of Business Research, 89, 448-454.

Qi, S. \& Nguyen, D. (2020). Government connections and credit access around the world: Evidence from discouraged borrowers. Journal of International Business Studies (Forthcoming).

Ruckes, M. (2004). Bank competition and credit standards. Review of Financial Studies, 17(4), 10731102.

Saffar, W., Wang, Y. \& Wei, K. C. (2019). The effect of firm-level political uncertainty on bank loan contracting. Available at SSRN 3354246.

Sojli, E. \& Tham, W. W. (2017). Foreign political connections. Journal of International Business Studies, 48(2), 244-266.

Stock, J. H. \& Yogo, M. (2002). Testing for weak instruments in linear IV regression (No. t0284). National Bureau of Economic Research.

Van Zanten, J. A. \& Van Tulder, R. (2018). Multinational enterprises and the sustainable development goals: An institutional approach to corporate engagement. Journal of International Business Policy, 1, 208-233.

Wellman, A. (2017). Mitigating political uncertainty. Review of Accounting Studies, 22, 217-250. 
Table 1

Summary statistics

\begin{tabular}{lcccccc}
\hline \hline Variables & Mean & Median & S.D. & Min. & Max. & Obs. \\
\hline All-in-spread-drawn (AISD) & 152.004 & 150 & 111.023 & 0 & 1,405 & 36,529 \\
Total cost of borrowing (TCB) & 110.44 & 81.72 & 99.5 & 5.06 & 773 & 20,083 \\
PSentiment & -0.020 & -0.066 & 0.991 & -4.665 & 4.268 & 36,529 \\
Facility amount & 57.036 & 29.167 & 149.939 & 0 & 12,250 & 36,529 \\
Financial covenants & 1.487 & 2 & 1.200 & 0 & 7 & 36,529 \\
Board size & 9.77 & 10 & 2.35 & 3 & 22 & 36,403 \\
Audit committee size & 3.98 & 4 & 1.02 & 1 & 9 & 36,403 \\
Number of Ind. NED with audit experience & 0.68 & 1 & 0.77 & 0 & 4 & 36,403 \\
Mean number of board directorships & 3.33 & 3.18 & 1.27 & 1 & 10.63 & 36,403 \\
Mean board age & 60.75 & 61.13 & 3.89 & 44.89 & 77.22 & 36,403 \\
Relationship dummy & 0.556 & 1 & 0.497 & 0 & 1 & 36,529 \\
Covenant dummy & 0.529 & 1 & 0.499 & 0 & 1 & 36,529 \\
Maturity & 52.500 & 60 & 17.581 & 0 & 180 & 36,529 \\
Firm size & 8.315 & 8.164 & 1.614 & 2.314 & 14.608 & 36,529 \\
NYSE & 0.799 & 1 & 0.401 & 0 & 1 & 36,529 \\
Profitability & 0.158 & 0.134 & 0.124 & -1.691 & 1.024 & 36,529 \\
MTB & 1.726 & 1.466 & 0.914 & 0.478 & 13.735 & 36,529 \\
Company rating & 13.38 & 12 & 5.98 & 1 & 23 & 34,726 \\
Bank size & 17.952 & 18.317 & 3.124 & 6.186 & 21.605 & 36,529 \\
Lead bank & 0.301 & 0 & 0.459 & 0 & 1 & 36,529 \\
Top 3 bank & 0.244 & 0 & 0.430 & 0 & 1 & 36,529 \\
No. countries MNE operates & 7.515 & 6 & 6.862 & 1 & 32 & 9,552 \\
No. subsidiaries & 17.025 & 10 & 27.478 & 1 & 256 & 9,552 \\
Foreign economies of scale & 0.856 & 0.428 & 1.216 & 0 & 4.93 & 9,552 \\
Sub. country political polarization & 1.262 & 1.345 & 0.656 & 0 & 2 & 9,461 \\
Realized volatility & 0.352 & 0.3 & 0.192 & 0.147 & 1.942 & 7,768 \\
Implied volatility & 0.323 & 0.3 & 0.122 & 0.159 & 1.091 & 7,577 \\
\hline \hline & & & & & & \\
\hline
\end{tabular}


Table 2

The relation between political sentiment and the cost of syndicated loans.

The dependent variable is AISD - all-in-spread-drawn (basis points) — is the sum of spread over LIBOR plus the facility fee. Definitions of all variables along with their sources are in appendix table A1. Robust standard errors clustered by bank in parentheses. Significance at the $1 \%, 5 \%$, and $10 \%$ level is indicated by $* * *, * *$, and $*$, respectively.

\begin{tabular}{|c|c|c|c|c|c|}
\hline & (1) & (2) & (3) & (4) & (5) \\
\hline PSentiment & $\begin{array}{c}-1.503 * * \\
(-2.47)\end{array}$ & $\begin{array}{c}-2.653 * * * \\
(-4.77)\end{array}$ & $\begin{array}{c}-4.519 * * * \\
(-9.25)\end{array}$ & $\begin{array}{c}-4.318 * * * \\
(-9.76)\end{array}$ & $\begin{array}{c}-4.137 * * * \\
(-10.45)\end{array}$ \\
\hline Relationship dummy & $\begin{array}{c}-16.109 * * * \\
(-14.12)\end{array}$ & $\begin{array}{c}-13.784 * * * \\
(-14.25)\end{array}$ & $\begin{array}{c}-11.273 * * * \\
(-10.97)\end{array}$ & $\begin{array}{c}-3.202 * * * \\
(-3.62)\end{array}$ & $\begin{array}{c}-3.000 * * * \\
(-3.80)\end{array}$ \\
\hline Covenant dummy & $\begin{array}{c}7.628 * * * \\
(3.65)\end{array}$ & $\begin{array}{c}16.819 * * * \\
(9.16)\end{array}$ & $\begin{array}{c}10.896^{* * * *} \\
(6.87)\end{array}$ & $\begin{array}{c}12.012 * * * \\
(9.21)\end{array}$ & $\begin{array}{c}11.011 * * * \\
(9.06)\end{array}$ \\
\hline Maturity & $\begin{array}{l}0.107 \\
(1.49)\end{array}$ & $\begin{array}{c}0.561 * * * \\
(9.25)\end{array}$ & $\begin{array}{c}0.420 * * * \\
(7.20)\end{array}$ & $\begin{array}{c}0.317 * * * \\
(5.78)\end{array}$ & $\begin{array}{c}-0.377 * * * \\
(-4.30)\end{array}$ \\
\hline Firm size & $\begin{array}{c}-20.997 * * * \\
(-20.63)\end{array}$ & $\begin{array}{c}-20.710 * * * \\
(-27.69)\end{array}$ & $\begin{array}{c}-22.573 * * * \\
(-28.24)\end{array}$ & $\begin{array}{c}-21.260 * * * \\
(-29.74)\end{array}$ & $\begin{array}{c}-19.490 * * * \\
(-28.85)\end{array}$ \\
\hline NYSE & $\begin{array}{c}-16.298 * * * \\
(-5.68)\end{array}$ & $\begin{array}{c}-9.821 * * * \\
(-3.62)\end{array}$ & $\begin{array}{l}-4.02 \\
(-1.36)\end{array}$ & $\begin{array}{l}-2.294 \\
(-0.87)\end{array}$ & $\begin{array}{l}-1.052 \\
(-0.45)\end{array}$ \\
\hline Profitability & $\begin{array}{c}-56.516 * * * \\
(-6.09)\end{array}$ & $\begin{array}{c}-82.962 * * * \\
(-8.97)\end{array}$ & $\begin{array}{c}-105.640 * * * \\
(-12.60)\end{array}$ & $\begin{array}{c}-100.276^{* * *} \\
(-11.65)\end{array}$ & $\begin{array}{c}-89.641 * * * \\
(-12.57)\end{array}$ \\
\hline MTB & $\begin{array}{c}-25.467 * * * \\
(-25.47)\end{array}$ & $\begin{array}{c}-18.479 * * * \\
(-21.09)\end{array}$ & $\begin{array}{c}-19.483^{* * *} \\
(-23.16)\end{array}$ & $\begin{array}{c}-19.389 * * * \\
(-19.94)\end{array}$ & $\begin{array}{c}-17.261 * * * \\
(-19.75)\end{array}$ \\
\hline Bank size & $\begin{array}{c}-3.719 * * * \\
(-7.39) \\
\end{array}$ & $\begin{array}{c}-1.282 * * * \\
(-3.49) \\
\end{array}$ & $\begin{array}{c}-1.366^{* * *} \\
(-4.19) \\
\end{array}$ & $\begin{array}{c}-1.240 * * * \\
(-3.56)\end{array}$ & $\begin{array}{c}-0.828 * * \\
(-2.51) \\
\end{array}$ \\
\hline Observations & 36,529 & 36,529 & 36,439 & 35,954 & 35,951 \\
\hline Adjusted $\mathrm{R}^{2}$ & 0.215 & 0.345 & 0.415 & 0.476 & 0.534 \\
\hline Cluster & Bank & Bank & Bank & Bank & Bank \\
\hline Bank FE & $\sqrt{ }$ & $\sqrt{ }$ & $\sqrt{ }$ & $\sqrt{ }$ & $\sqrt{ }$ \\
\hline Year FE & & $\sqrt{ }$ & $\sqrt{ }$ & $\sqrt{ }$ & $\sqrt{ }$ \\
\hline SIC3 FE & & & $\sqrt{ }$ & $\sqrt{ }$ & $\sqrt{ }$ \\
\hline Purpose FE & & & & $\sqrt{ }$ & $\sqrt{ }$ \\
\hline Loan type FE & & & & & $\sqrt{ }$ \\
\hline
\end{tabular}


Table 3

The relation between political sentiment and the cost of syndicated loans controlling for boardroom characteristics.

The dependent variable is $A I S D$ — all-in-spread-drawn (bps), — defined as the sum of spread over LIBOR plus the facility fee. PSentiment denotes a firm's overall political sentiment and it is an index that is constructed by Hassan et al. (2019). This variable is standardized with zero mean and a standard deviation equal to one.

Relationship dummy takes value one if the bank lent to the same borrower in the five years prior to the current loan and zero otherwise. Covenant is a dummy taking value one when a loan has a covenant and zero otherwise. Maturity denotes the loan duration in months. Firm size denotes a firm's natural logarithm of total assets. NYSE is an indicator that takes value one for firms with presence at the New York Stock Exchange. Profitability is the ratio on pre-tax profits to total assets. MTB denotes market-to-book value. Bank size is the natural logarithm of total assets. Definitions of all variables along with their sources are in appendix table A1. Robust standard errors clustered by bank in parentheses. Significance at the $1 \%, 5 \%$, and $10 \%$ level is indicated by $* * *, * *$, and $*$, respectively.

\begin{tabular}{|c|c|c|c|c|c|c|}
\hline & (1) & (2) & (3) & (4) & (5) & (6) \\
\hline PSentiment & $\begin{array}{c}-4.264 * * * \\
(-8.53)\end{array}$ & $\begin{array}{c}-4.296 * * * \\
(-8.46)\end{array}$ & $\begin{array}{c}-4.351^{* * * *} \\
(-8.62)\end{array}$ & $\begin{array}{c}-4.378 * * * \\
(-8.66)\end{array}$ & $\begin{array}{c}-4.721 * * * \\
(-8.75)\end{array}$ & $\begin{array}{l}-4.320 * * * \\
(-10.10)\end{array}$ \\
\hline Relationship dummy & $\begin{array}{c}-11.236^{* * *} \\
(-10.91)\end{array}$ & $\begin{array}{c}-11.181 * * * \\
(-10.99)\end{array}$ & $\begin{array}{c}-11.092 * * * \\
(-10.87)\end{array}$ & $\begin{array}{c}-10.941^{* * *} \\
(-10.84)\end{array}$ & $\begin{array}{c}-10.969 * * * \\
(-10.79)\end{array}$ & $\begin{array}{c}-2.704 * * * \\
(-3.44)\end{array}$ \\
\hline Covenant dummy & $\begin{array}{c}10.574 * * * \\
(6.58)\end{array}$ & $\begin{array}{c}10.299 * * * \\
(6.40)\end{array}$ & $\begin{array}{c}10.206^{* * * *} \\
(6.33)\end{array}$ & $\begin{array}{c}10.406^{* * * *} \\
(6.43)\end{array}$ & $\begin{array}{c}10.418 * * * \\
(6.51)\end{array}$ & $\begin{array}{c}10.730 * * * \\
(8.57)\end{array}$ \\
\hline Maturity & $\begin{array}{c}0.406 * * * \\
(6.99)\end{array}$ & $\begin{array}{c}0.406 * * * \\
(7.06)\end{array}$ & $\begin{array}{l}0.405^{* * *} \\
(7.02)\end{array}$ & $\begin{array}{c}0.402 * * * \\
(6.99)\end{array}$ & $\begin{array}{c}0.395 * * * \\
(6.90)\end{array}$ & $\begin{array}{c}-0.392 * * * \\
(-4.46)\end{array}$ \\
\hline Firm size & $\begin{array}{c}-20.715 * * * \\
(-27.09)\end{array}$ & $\begin{array}{c}-20.544 * * * \\
(-26.85)\end{array}$ & $\begin{array}{c}-20.501 * * * \\
(-26.81)\end{array}$ & $\begin{array}{c}-21.251 * * * \\
(-26.74)\end{array}$ & $\begin{array}{c}-21.171 * * * \\
(-27.21)\end{array}$ & $\begin{array}{c}-19.063 * * * \\
(-26.82)\end{array}$ \\
\hline NYSE & $\begin{array}{l}-3.36 \\
(-1.13)\end{array}$ & $\begin{array}{l}-2.984 \\
(-1.02)\end{array}$ & $\begin{array}{l}-2.887 \\
(-0.98)\end{array}$ & $\begin{array}{l}-3.139 \\
(-1.07)\end{array}$ & $\begin{array}{l}-2.368 \\
(-0.83)\end{array}$ & $\begin{array}{l}-0.089 \\
(-0.04)\end{array}$ \\
\hline Profitability & $\begin{array}{c}-104.291 * * * \\
(-12.34)\end{array}$ & $\begin{array}{c}-103.651^{* * *} \\
(-12.38)\end{array}$ & $\begin{array}{c}-104.220 * * * \\
(-12.50)\end{array}$ & $\begin{array}{c}-103.796^{* * *} \\
(-12.59)\end{array}$ & $\begin{array}{c}-101.395^{* * *} \\
(-12.99)\end{array}$ & $\begin{array}{c}-86.588 * * * \\
(-12.59)\end{array}$ \\
\hline MTB & $\begin{array}{c}-19.429 * * * \\
(-23.04)\end{array}$ & $\begin{array}{c}-19.335^{* * *} \\
(-22.56)\end{array}$ & $\begin{array}{c}-19.355^{* * *} \\
(-22.47)\end{array}$ & $\begin{array}{c}-19.618 * * * \\
(-22.66)\end{array}$ & $\begin{array}{c}-19.819 * * * \\
(-23.34)\end{array}$ & $\begin{array}{c}-17.740 * * * \\
(-20.34)\end{array}$ \\
\hline Bank size & $\begin{array}{c}-1.459 * * * \\
(-4.50)\end{array}$ & $\begin{array}{c}-1.385 * * * \\
(-4.20)\end{array}$ & $\begin{array}{c}-1.388 * * * \\
(-4.19)\end{array}$ & $\begin{array}{c}-1.404 * * * \\
(-4.22)\end{array}$ & $\begin{array}{c}-1.370 * * * \\
(-4.06)\end{array}$ & $\begin{array}{c}-0.809^{* *} \\
(-2.40)\end{array}$ \\
\hline No. directors & $\begin{array}{c}-2.223 * * * \\
(-6.45)\end{array}$ & $\begin{array}{c}-1.690 * * * \\
(-4.84)\end{array}$ & $\begin{array}{c}-1.702 * * * \\
(-4.84)\end{array}$ & $\begin{array}{c}-1.730 * * * \\
(-4.92)\end{array}$ & $\begin{array}{c}-1.588 * * * \\
(-4.43)\end{array}$ & $\begin{array}{c}-1.052 * * * \\
(-4.09)\end{array}$ \\
\hline Audit committee size & & $\begin{array}{c}-3.350 * * * \\
(-4.43)\end{array}$ & $\begin{array}{c}-3.516 * * * \\
(-4.69)\end{array}$ & $\begin{array}{c}-3.617 * * * \\
(-4.83)\end{array}$ & $\begin{array}{c}-3.137 * * * \\
(-4.52)\end{array}$ & $\begin{array}{c}-1.818 * * * \\
(-3.08)\end{array}$ \\
\hline No. independent directors & & & $\begin{array}{c}2.259 * * * \\
(2.77)\end{array}$ & $\begin{array}{c}2.166 * * * \\
(2.66)\end{array}$ & $\begin{array}{l}1.515^{*} \\
(1.67)\end{array}$ & $\begin{array}{l}1.619 * * \\
(2.03)\end{array}$ \\
\hline Mean directorship & & & & $\begin{array}{c}1.945 * * * \\
(3.75)\end{array}$ & $\begin{array}{c}2.148 * * * \\
(4.13)\end{array}$ & $\begin{array}{c}2.602 * * * \\
(5.86)\end{array}$ \\
\hline Director's average age & & & & & $\begin{array}{c}-1.159 * * * \\
(-4.59)\end{array}$ & $\begin{array}{c}-0.872 * * * \\
(-4.27)\end{array}$ \\
\hline Observations & 36,439 & 36,439 & 36,439 & 36,403 & 36,403 & 35,914 \\
\hline Adjusted $\mathrm{R}^{2}$ & 0.416 & 0.416 & 0.416 & 0.417 & 0.418 & 0.536 \\
\hline Cluster & Bank & Bank & Bank & Bank & Bank & Bank \\
\hline Bank FE & $\sqrt{ }$ & $\sqrt{ }$ & $\sqrt{ }$ & $\sqrt{ }$ & $\sqrt{ }$ & $\sqrt{ }$ \\
\hline Year FE & $\sqrt{ }$ & $\sqrt{ }$ & $\sqrt{ }$ & $\sqrt{ }$ & $\sqrt{ }$ & $\sqrt{ }$ \\
\hline SIC3 FE & $\sqrt{ }$ & $\sqrt{ }$ & $\sqrt{ }$ & $\sqrt{ }$ & $\sqrt{ }$ & $\sqrt{ }$ \\
\hline Purpose FE & - & - & - & - & - & $\sqrt{ }$ \\
\hline Loan type FE & - & - & - & - & - & $\sqrt{ }$ \\
\hline
\end{tabular}




\section{Table 4}

The relation between political sentiment and the cost of syndicated loans excluding the top 3 lead arrangers.

The dependent variable is $A I S D$-all-in-spread-drawn (bps), — defined as the sum of spread over LIBOR plus the facility fee. PSentiment denotes a firm's overall political sentiment and it is an index that is constructed by Hassan et al. (2019). This variable is standardized with zero mean and a standard deviation equal to one. Relationship dummy takes value one if the bank lent to the same borrower in the five years prior to the current loan and zero otherwise. Covenant is a dummy taking value one when a loan has a covenant and zero otherwise. Maturity denotes the loan duration in months. Firm size denotes a firm's natural logarithm of total assets. NYSE is an indicator that takes value one for firms with presence at the New York Stock Exchange. Profitability is the ratio on pre-tax profits to total assets. MTB denotes marketto-book value. Bank size is the natural logarithm of total assets. Definitions of all variables along with their sources are in appendix table A1. Robust standard errors clustered by bank and t-statistics are reported in parentheses in parentheses. Significance at the $1 \%, 5 \%$, and $10 \%$ level is indicated by ***,**, and *, respectively.

\begin{tabular}{|c|c|c|c|c|}
\hline & (1) & (2) & (3) & (4) \\
\hline PSentiment & $\begin{array}{c}-2.818 * * * \\
(-4.55)\end{array}$ & $\begin{array}{c}-3.966^{* * *} \\
(-6.76)\end{array}$ & $\begin{array}{c}-5.287 * * * \\
(-8.19)\end{array}$ & $\begin{array}{c}-4.407 * * * \\
(-7.39)\end{array}$ \\
\hline Relationship dummy & $\begin{array}{c}-18.075 * * * \\
(-12.93)\end{array}$ & $\begin{array}{c}-14.345 * * * \\
(-10.70)\end{array}$ & $\begin{array}{c}-11.571 * * * \\
(-7.94)\end{array}$ & $\begin{array}{c}-3.417 * * * \\
(-3.16)\end{array}$ \\
\hline Covenant dummy & $\begin{array}{c}9.284 * * * \\
(4.01)\end{array}$ & $\begin{array}{c}18.928 * * * \\
(9.86)\end{array}$ & $\begin{array}{c}12.083 * * * \\
(6.99)\end{array}$ & $\begin{array}{c}10.931 * * * \\
(9.26)\end{array}$ \\
\hline Maturity & $\begin{array}{l}0.01 \\
(0.13)\end{array}$ & $\begin{array}{l}0.519 * * * \\
(8.91)\end{array}$ & $\begin{array}{c}0.396 * * * \\
(7.68)\end{array}$ & $\begin{array}{c}-0.403 * * * \\
(-4.38)\end{array}$ \\
\hline Firm size & $\begin{array}{c}-21.344 * * * \\
(-16.10)\end{array}$ & $\begin{array}{c}-20.781 * * * \\
(-23.49)\end{array}$ & $\begin{array}{c}-22.601 * * * \\
(-22.57)\end{array}$ & $\begin{array}{c}-19.721 * * * \\
(-20.88)\end{array}$ \\
\hline NYSE & $\begin{array}{c}-14.244 * * * \\
(-4.56)\end{array}$ & $\begin{array}{c}-7.917 * * * \\
(-2.70)\end{array}$ & $\begin{array}{l}-2.308 \\
(-0.72)\end{array}$ & $\begin{array}{l}0.204 \\
(0.08)\end{array}$ \\
\hline Profitability & $\begin{array}{c}-46.760 * * * \\
(-4.19)\end{array}$ & $\begin{array}{c}-75.192 * * * \\
(-7.37)\end{array}$ & $\begin{array}{c}-102.614 * * * \\
(-9.92)\end{array}$ & $\begin{array}{c}-92.367 * * * \\
(-9.19)\end{array}$ \\
\hline MTB & $\begin{array}{c}-23.928 * * * \\
(-18.20)\end{array}$ & $\begin{array}{c}-16.904 * * * \\
(-15.81)\end{array}$ & $\begin{array}{c}-18.897 * * * \\
(-18.89)\end{array}$ & $\begin{array}{c}-17.050^{* * * *} \\
(-16.58)\end{array}$ \\
\hline Bank size & $\begin{array}{c}-2.574 * * * \\
(-4.81)\end{array}$ & $\begin{array}{c}-1.454 * * * \\
(-3.01)\end{array}$ & $\begin{array}{c}-1.645 * * * \\
(-3.36)\end{array}$ & $\begin{array}{c}-1.271 * * * \\
(-2.70)\end{array}$ \\
\hline Observations & 27140 & 27140 & 27073 & 26748 \\
\hline Adjusted $\mathrm{R}^{2}$ & 0.239 & 0.371 & 0.438 & 0.546 \\
\hline Cluster & Bank & Bank & Bank & Bank \\
\hline Bank FE & $\sqrt{ }$ & $\sqrt{ }$ & $\sqrt{ }$ & $\sqrt{ }$ \\
\hline Year FE & - & $\sqrt{ }$ & $\sqrt{ }$ & $\sqrt{ }$ \\
\hline SIC3 FE & - & - & $\sqrt{ }$ & $\sqrt{ }$ \\
\hline Purpose FE & - & - & - & $\sqrt{ }$ \\
\hline Loan type FE & - & - & - & $\sqrt{ }$ \\
\hline
\end{tabular}




\section{Table 5}

The relation between political sentiment and the cost of syndicated loans controlling for company credit ratings.

The dependent variable is $A I S D$ —all-in-spread-drawn (bps), — defined as the sum of spread over LIBOR plus the facility fee. PSentiment denotes a firm's overall political sentiment and it is an index that is constructed by Hassan et al. (2019). This variable is standardized with zero mean and a standard deviation equal to one. Definitions of all variables along with their sources are in appendix table A1. Robust standard errors clustered by bank and t-statistics are reported in parentheses in parentheses. Significance at the $1 \%$, $5 \%$, and $10 \%$ level is indicated by $* * *, * *$, and $*$, respectively.

\begin{tabular}{lcccc}
\hline \hline & $\mathbf{( 1 )}$ & $\mathbf{( 2 )}$ & $\mathbf{( 3 )}$ & $\mathbf{( 4 )}$ \\
\hline PSentiment & $-1.954^{* * *}$ & $-3.011^{* * *}$ & $-4.690^{* * *}$ & $-4.243^{* * *}$ \\
Relationship dummy & $(-3.49)$ & $(-5.81)$ & $(-9.13)$ & $(-10.54)$ \\
& $-15.519^{* * *}$ & $-13.280^{* * *}$ & $-10.754^{* * *}$ & $-2.350^{* * *}$ \\
Covenant dummy & $(-13.16)$ & $(-14.69)$ & $(-10.63)$ & $(-2.81)$ \\
& $7.188^{* * *}$ & $16.564^{* * *}$ & $10.456^{* * *}$ & $10.635^{* * *}$ \\
Maturity & $(3.49)$ & $(9.18)$ & $(6.66)$ & $(8.59)$ \\
& 0.105 & $0.562^{* * *}$ & $0.414^{* * *}$ & $-0.360^{* * *}$ \\
Company rating & $(1.54)$ & $(9.59)$ & $(7.25)$ & $(-4.15)$ \\
& $3.041^{* * *}$ & $2.056^{* * *}$ & $2.090^{* * *}$ & $1.832^{* * *}$ \\
Firm size & $(9.67)$ & $(6.37)$ & $(7.05)$ & $(7.19)$ \\
& $-14.823^{* * *}$ & $-16.643^{* * *}$ & $-18.398^{* * *}$ & $-15.731^{* * *}$ \\
NYSE & $(-12.59)$ & $(-18.02)$ & $(-19.07)$ & $(-18.88)$ \\
& $-10.024^{* * *}$ & $-5.277^{* *}$ & -1.148 & 1.128 \\
Profitability & $(-3.78)$ & $(-2.04)$ & $(-0.39)$ & $(0.50)$ \\
& $-48.302^{* * *}$ & $-79.267^{* * *}$ & $-106.248^{* * *}$ & $-96.214 * * *$ \\
MTB & $(-5.12)$ & $(-8.51)$ & $(-13.46)$ & $(-15.06)$ \\
& $-26.237^{* * *}$ & $-18.530^{* * *}$ & $-19.787^{* * *}$ & $-17.157^{* * *}$ \\
Bank size & $(-24.67)$ & $(-19.31)$ & $(-21.91)$ & $(-18.92)$ \\
& $-2.647^{* * *}$ & $-0.949^{*}$ & $-1.280^{* * *}$ & -0.618 \\
Observations & $(-4.75)$ & $(-1.92)$ & $(-2.94)$ & $(-1.45)$ \\
Adjusted R ${ }^{2}$ & 35,115 & 35,115 & 35,024 & 34,726 \\
Cluster & 0.231 & 0.354 & 0.424 & 0.542 \\
Bank FE & $B a n k$ & $B a n k$ & $B a n k$ & $B a n k$ \\
Year FE & $\sqrt{ }$ & $\sqrt{ }$ & $\sqrt{ }$ & $\sqrt{ }$ \\
SIC3 FE & - & $\sqrt{ }$ & $\sqrt{ }$ & $\sqrt{ }$ \\
Purpose FE & - & - & - & $\sqrt{ }$ \\
Loan type FE & - & - & - & $\sqrt{ }$ \\
\hline \hline & - & - & & \\
\hline
\end{tabular}


Table 6

The relation between political sentiment and the cost of syndicated loans controlling for time varying fixed effects.

The dependent variable is AISD — all-in-spread-drawn (bps), — defined as the sum of spread over LIBOR plus the facility fee. PSentiment denotes a firm's overall political sentiment and it is an index that is constructed by Hassan et al. (2019). This variable is standardized with zero mean and a standard deviation equal to one. Definitions of all variables along with their sources are in appendix table A1. Robust standard errors clustered by bank and t-statistics are reported in parentheses in parentheses. Significance at the $1 \%, 5 \%$, and $10 \%$ level is indicated by $* * *, * *$, and $*$, respectively.

\begin{tabular}{|c|c|c|c|c|c|c|c|c|c|}
\hline & (1) & (2) & (3) & (4) & (5) & (6) & (7) & (8) & (9) \\
\hline PSentiment & $\begin{array}{c}-4.443 * * * \\
(-9.38)\end{array}$ & $\begin{array}{c}-4.129 * * * \\
(-9.78)\end{array}$ & $\begin{array}{l}-3.962 * * * \\
(-10.35)\end{array}$ & $\begin{array}{c}-3.428 * * * \\
(-5.40)\end{array}$ & $\begin{array}{c}-2.875 * * * \\
(-4.64)\end{array}$ & $\begin{array}{c}-2.888 * * * \\
(-5.27)\end{array}$ & $\begin{array}{c}-2.730 * * * \\
(-5.23)\end{array}$ & $\begin{array}{c}-2.596 * * * \\
(-5.40)\end{array}$ & $\begin{array}{c}-2.449 * * * \\
(-5.14)\end{array}$ \\
\hline Relationship dummy & $\begin{array}{c}-11.977 * * * \\
(-12.07)\end{array}$ & $\begin{array}{c}-3.856^{* * * *} \\
(-4.67)\end{array}$ & $\begin{array}{c}-3.417 * * * \\
(-4.45)\end{array}$ & $\begin{array}{c}-11.583^{* * * *} \\
(-10.69)\end{array}$ & $\begin{array}{c}-4.105^{* * *} \\
(-4.61)\end{array}$ & $\begin{array}{c}-3.531 * * * \\
(-3.98)\end{array}$ & $\begin{array}{c}-4.077 * * * \\
(-4.17)\end{array}$ & $\begin{array}{c}-3.546 * * * \\
(-3.76)\end{array}$ & $\begin{array}{c}-2.890 * * * \\
(-3.28)\end{array}$ \\
\hline Covenant dummy & $\begin{array}{c}10.584^{* * * *} \\
(6.70)\end{array}$ & $\begin{array}{c}11.754 * * * \\
(8.51)\end{array}$ & $\begin{array}{c}10.924^{* * * *} \\
(8.39)\end{array}$ & $\begin{array}{c}9.712 * * * \\
(5.80)\end{array}$ & $\begin{array}{c}9.905^{* * *} \\
(6.71)\end{array}$ & $\begin{array}{c}9.385 * * * \\
(6.65)\end{array}$ & $\begin{array}{c}10.965^{* * * *} \\
(7.97)\end{array}$ & $\begin{array}{c}10.215^{* * * *} \\
(7.36)\end{array}$ & $\begin{array}{c}10.468 * * * \\
(7.97)\end{array}$ \\
\hline Maturity & $\begin{array}{c}0.414 * * * \\
(6.94)\end{array}$ & $\begin{array}{c}0.305^{* * * *} \\
(5.43)\end{array}$ & $\begin{array}{c}-0.370 * * * \\
(-4.13)\end{array}$ & $\begin{array}{c}0.418 * * * \\
(7.16)\end{array}$ & $\begin{array}{c}0.297 * * * \\
(5.43)\end{array}$ & $\begin{array}{c}-0.190 * * \\
(-2.31)\end{array}$ & $\begin{array}{c}0.288 * * * \\
(4.73)\end{array}$ & $\begin{array}{c}-0.199 * * \\
(-2.18)\end{array}$ & $\begin{array}{c}-0.209 * * \\
(-2.37)\end{array}$ \\
\hline Firm size & $\begin{array}{c}-22.401 * * * \\
(-26.72)\end{array}$ & $\begin{array}{c}-21.116^{* * *} \\
(-27.92)\end{array}$ & $\begin{array}{c}-19.436 * * * \\
(-26.97)\end{array}$ & $\begin{array}{c}-22.150 * * * \\
(-23.81)\end{array}$ & $\begin{array}{c}-20.539 * * * \\
(-23.12)\end{array}$ & $\begin{array}{c}-19.323 * * * \\
(-22.84)\end{array}$ & $\begin{array}{c}-20.734 * * * \\
(-23.93)\end{array}$ & $\begin{array}{c}-19.450 * * * \\
(-23.90)\end{array}$ & $\begin{array}{c}-19.224 * * * \\
(-25.16)\end{array}$ \\
\hline NYSE & $\begin{array}{r}-3.629 \\
(-1.21)\end{array}$ & $\begin{array}{l}-1.971 \\
(-0.74)\end{array}$ & $\begin{array}{l}-0.853 \\
(-0.36)\end{array}$ & $\begin{array}{c}-7.599 * * * \\
(-2.79)\end{array}$ & $\begin{array}{c}-5.656^{* *} \\
(-2.06)\end{array}$ & $\begin{array}{c}-4.358^{*} \\
(-1.81)\end{array}$ & $\begin{array}{c}-6.962 * * \\
(-2.57)\end{array}$ & $\begin{array}{c}-5.679 * * \\
(-2.36)\end{array}$ & $\begin{array}{c}-5.329 * * \\
(-2.23)\end{array}$ \\
\hline Profitability & $\begin{array}{c}-103.502 * * * \\
(-11.72)\end{array}$ & $\begin{array}{c}-99.207 * * * \\
(-11.18)\end{array}$ & $\begin{array}{c}-88.633 * * * \\
(-12.15)\end{array}$ & $\begin{array}{c}-133.942 * * * \\
(-10.97)\end{array}$ & $\begin{array}{c}-134.553 * * * \\
(-10.91)\end{array}$ & $\begin{array}{c}-120.890 * * * \\
(-11.39)\end{array}$ & $\begin{array}{c}-132.804 * * * \\
(-11.32)\end{array}$ & $\begin{array}{c}-120.787 * * * \\
(-11.84)\end{array}$ & $\begin{array}{c}-115.085 * * * \\
(-11.79)\end{array}$ \\
\hline MTB & $\begin{array}{c}-19.519 * * * \\
(-24.35)\end{array}$ & $\begin{array}{c}-19.328 * * * \\
(-20.44)\end{array}$ & $\begin{array}{c}-17.347 * * * \\
(-20.35)\end{array}$ & $\begin{array}{c}-16.400 * * * \\
(-19.27)\end{array}$ & $\begin{array}{c}-15.444 * * * \\
(-18.50)\end{array}$ & $\begin{array}{c}-14.247 * * * \\
(-18.67)\end{array}$ & $\begin{array}{c}-16.127 * * * \\
(-17.69)\end{array}$ & $\begin{array}{c}-14.743 * * * \\
(-17.88)\end{array}$ & $\begin{array}{c}-14.625^{* * *} \\
(-18.12)\end{array}$ \\
\hline Bank size & $\begin{array}{c}-1.191 * * * \\
(-3.34)\end{array}$ & $\begin{array}{c}-1.269 * * * \\
(-3.81)\end{array}$ & $\begin{array}{c}-0.986 * * * \\
(-3.02) \\
\end{array}$ & $\begin{array}{c}-1.797 * * * \\
(-3.45)\end{array}$ & $\begin{array}{c}-1.404 * * * \\
(-2.98)\end{array}$ & $\begin{array}{l}-1.109 * * \\
(-2.43) \\
\end{array}$ & $\begin{array}{c}-1.222 * * * \\
(-2.84)\end{array}$ & $\begin{array}{c}-0.874 * * \\
(-2.20) \\
\end{array}$ & $\begin{array}{c}-0.872 * * \\
(-2.51) \\
\end{array}$ \\
\hline Observations & 36,158 & 35,670 & 35,667 & 36,056 & 35,567 & 35,564 & 35,553 & 35,550 & 35,537 \\
\hline Adjusted $\mathrm{R}^{2}$ & 0.422 & 0.483 & 0.54 & 0.56 & 0.605 & 0.646 & 0.622 & 0.66 & 0.676 \\
\hline Cluster & Bank & Bank & Bank & Bank & Bank & Bank & Bank & Bank & Bank \\
\hline Bank * Year & $\sqrt{ }$ & $\sqrt{ }$ & $\sqrt{ }$ & $\sqrt{ }$ & $\sqrt{ }$ & $\sqrt{ }$ & $\sqrt{ }$ & $\sqrt{ }$ & $\sqrt{ }$ \\
\hline SIC3 & $\sqrt{ }$ & $\sqrt{ }$ & $\sqrt{ }$ & - & - & - & - & - & - \\
\hline Purpose & - & $\sqrt{ }$ & $\sqrt{ }$ & - & $\sqrt{ }$ & $\sqrt{ }$ & - & $\sqrt{ }$ & - \\
\hline Loan type & - & - & $\sqrt{ }$ & - & - & $\sqrt{ }$ & - & $\sqrt{ }$ & - \\
\hline SIC3 * Year & - & - & - & $\sqrt{ }$ & $\sqrt{ }$ & $\sqrt{ }$ & $\sqrt{ }$ & $\sqrt{ }$ & $\sqrt{ }$ \\
\hline Purpose * Year & - & - & - & - & - & - & $\sqrt{ }$ & - & $\sqrt{ }$ \\
\hline Loan type * Year & - & - & - & - & - & - & - & - & $\sqrt{ }$ \\
\hline
\end{tabular}


Table 7

The relation between political sentiment and the cost of syndicated loans in different industries.

The dependent variable is AISD — all-in-spread-drawn (bps), — defined as the sum of spread over LIBOR plus the facility fee. PSentiment denotes a firm's overall political sentiment and it is an index that is constructed by Hassan et al. (2019). This variable is standardized with zero mean and a standard deviation equal to one. Definitions of all variables along with their sources are in appendix table A1. Robust standard errors clustered by bank and t-statistics are reported in parentheses in parentheses. Significance at the $1 \%, 5 \%$, and $10 \%$ level is indicated by $* * *, * *$, and $*$, respectively.

\begin{tabular}{|c|c|c|c|c|c|c|c|c|}
\hline & Mining & Construction & Manufacturing & Transport & Wholesale & Retail & Finance & Services \\
\hline PSentiment & $\begin{array}{c}-7.930 * * * \\
(-3.70)\end{array}$ & $\begin{array}{l}-2.865 \\
(-1.32)\end{array}$ & $\begin{array}{c}-2.988 * * * \\
(-3.23)\end{array}$ & $\begin{array}{c}-4.891 * * * \\
(-5.33)\end{array}$ & $\begin{array}{l}-5.15 \\
(-1.24)\end{array}$ & $\begin{array}{l}1.277 \\
(0.72)\end{array}$ & $\begin{array}{l}-0.524 \\
(-0.41)\end{array}$ & $\begin{array}{l}-0.923 \\
(-0.70)\end{array}$ \\
\hline Relationship dummy & $\begin{array}{c}-13.802 * * * \\
(-3.51)\end{array}$ & $\begin{array}{c}-9.131 * * * \\
(-3.49)\end{array}$ & $\begin{array}{c}-4.446^{* * * *} \\
(-2.84)\end{array}$ & $\begin{array}{c}1.865 \\
(1.12)\end{array}$ & $\begin{array}{l}3.495 \\
(0.88)\end{array}$ & $\begin{array}{l}-1.875 \\
(-0.64)\end{array}$ & $\begin{array}{c}9.244 * * * \\
(3.09)\end{array}$ & $\begin{array}{l}-4.566 \\
(-1.34)\end{array}$ \\
\hline Covenant dummy & $\begin{array}{c}20.691^{* * * *} \\
(5.06)\end{array}$ & $\begin{array}{c}11.426^{* * *} * \\
(3.70)\end{array}$ & $\begin{array}{c}21.932 * * * \\
(11.75)\end{array}$ & $\begin{array}{c}9.178 * * * \\
(3.16)\end{array}$ & $\begin{array}{l}16.740 * * * \\
(2.81)\end{array}$ & $\begin{array}{l}-7.221 \\
(-1.64)\end{array}$ & $\begin{array}{c}16.997 * * * \\
(4.82)\end{array}$ & $\begin{array}{c}15.361^{* * * *} \\
(5.53)\end{array}$ \\
\hline Maturity & $\begin{array}{l}-0.176 \\
(-0.72)\end{array}$ & $\begin{array}{c}-1.369 * * * \\
(-4.38)\end{array}$ & $\begin{array}{c}-0.607 * * * \\
(-4.37)\end{array}$ & $\begin{array}{l}-0.172 \\
(-1.38)\end{array}$ & $\begin{array}{c}0.563 * * * \\
(3.50)\end{array}$ & $\begin{array}{c}-0.547 * * * \\
(-2.96)\end{array}$ & $\begin{array}{c}-0.288 * * \\
(-2.23)\end{array}$ & $\begin{array}{c}-0.469 * * * \\
(-2.95)\end{array}$ \\
\hline Firm size & $\begin{array}{c}-20.260 * * * \\
(-10.98)\end{array}$ & $\begin{array}{c}-32.456 * * * \\
(-13.82)\end{array}$ & $\begin{array}{c}-14.618 * * * \\
(-10.80)\end{array}$ & $\begin{array}{c}-9.902 * * * \\
(-5.96)\end{array}$ & $\begin{array}{c}-16.081 * * * \\
(-5.84)\end{array}$ & $\begin{array}{c}-25.426^{* * *} \\
(-13.82)\end{array}$ & $\begin{array}{c}-16.578 * * * \\
(-11.37)\end{array}$ & $\begin{array}{c}-25.803 * * * \\
(-20.34)\end{array}$ \\
\hline NYSE & $\begin{array}{c}6.912 \\
(1.16)\end{array}$ & $\begin{array}{c}-24.648 \\
(-1.20)\end{array}$ & $\begin{array}{l}1.406 \\
(0.55)\end{array}$ & $\begin{array}{c}-71.221 * * * \\
(-15.97)\end{array}$ & $\begin{array}{c}-10.385 \\
(-1.13)\end{array}$ & $\begin{array}{c}14.195 * * \\
(2.59)\end{array}$ & $\begin{array}{c}-23.642 * * * \\
(-4.32)\end{array}$ & $\begin{array}{l}7.86 \\
(1.58)\end{array}$ \\
\hline Profitability & $\begin{array}{r}-15.163 \\
(-1.29)\end{array}$ & $\begin{array}{c}-174.161^{* * *} \\
(-3.46)\end{array}$ & $\begin{array}{c}-127.430 * * * \\
(-11.89)\end{array}$ & $\begin{array}{r}-22.933 \\
(-0.80)\end{array}$ & $\begin{array}{r}28.873 \\
(0.66)\end{array}$ & $\begin{array}{c}-88.769 * * * \\
(-5.62)\end{array}$ & $\begin{array}{r}24.412 \\
(1.07)\end{array}$ & $\begin{array}{c}-55.269 * * \\
(-1.98)\end{array}$ \\
\hline МТB & $\begin{array}{c}-8.532 * * * \\
(-2.84)\end{array}$ & $\begin{array}{c}-45.243 * * * \\
(-7.08)\end{array}$ & $\begin{array}{c}-14.647 * * * \\
(-15.59)\end{array}$ & $\begin{array}{c}-38.043^{* * * *} \\
(-8.48)\end{array}$ & $\begin{array}{c}-34.024 * * * \\
(-5.70)\end{array}$ & $\begin{array}{c}-21.884 * * * \\
(-15.97)\end{array}$ & $\begin{array}{c}-24.169 * * * \\
(-11.65)\end{array}$ & $\begin{array}{c}-16.335^{* * *} \\
(-10.13)\end{array}$ \\
\hline Bank size & $\begin{array}{c}0.447 \\
(0.31)\end{array}$ & $\begin{array}{l}-2.172 \\
(-1.59)\end{array}$ & $\begin{array}{c}-1.007 * * \\
(-2.19) \\
\end{array}$ & $\begin{array}{l}1.755 \\
(1.04)\end{array}$ & $\begin{array}{l}-1.42 \\
(-0.84)\end{array}$ & $\begin{array}{l}-0.915 \\
(-0.77) \\
\end{array}$ & $\begin{array}{r}-11.694 \\
(-1.42) \\
\end{array}$ & $\begin{array}{l}-1.682 * \\
(-1.77) \\
\end{array}$ \\
\hline Observations & 2,691 & 1,020 & 13,377 & 5,337 & 1,342 & 3,356 & 2,709 & 5,896 \\
\hline Adjusted $\mathrm{R}^{2}$ & 0.474 & 0.647 & 0.492 & 0.526 & 0.61 & 0.607 & 0.667 & 0.505 \\
\hline Cluster & Bank & Bank & Bank & Bank & Bank & Bank & Bank & Bank \\
\hline Bank FE & $\sqrt{ }$ & $\sqrt{ }$ & $\sqrt{ }$ & $\sqrt{ }$ & $\sqrt{ }$ & $\sqrt{ }$ & $\sqrt{ }$ & $\sqrt{ }$ \\
\hline Year FE & $\sqrt{ }$ & $\sqrt{ }$ & $\sqrt{ }$ & $\sqrt{ }$ & $\sqrt{ }$ & $\sqrt{ }$ & $\sqrt{ }$ & $\sqrt{ }$ \\
\hline Purpose FE & $\sqrt{ }$ & $\sqrt{ }$ & $\sqrt{ }$ & $\sqrt{ }$ & $\sqrt{ }$ & $\sqrt{ }$ & $\sqrt{ }$ & $\sqrt{ }$ \\
\hline Loan type FE & $\sqrt{ }$ & $\sqrt{ }$ & $\sqrt{ }$ & $\sqrt{ }$ & $\sqrt{ }$ & $\sqrt{ }$ & $\sqrt{ }$ & $\sqrt{ }$ \\
\hline
\end{tabular}


Table 8

Political sentiment and foreign operations.

The dependent variable is AISD — all-in-spread-drawn (basis points) — is the sum of spread over LIBOR plus the facility fee. Definitions of all variables along with their sources are in appendix table A1. Robust standard errors clustered by bank and $t$-statistics are reported in parentheses. Significance at the $1 \%, 5 \%$, and $10 \%$ level is indicated by $* * *, * *$, and $*$, respectively.

\begin{tabular}{|c|c|c|c|c|}
\hline & (1) & (2) & (3) & (4) \\
\hline PSentiment & $\begin{array}{c}-8.465^{* * *} \\
(-4.41)\end{array}$ & $\begin{array}{c}-5.772 * * * \\
(-3.58)\end{array}$ & $\begin{array}{c}-7.514 * * * \\
(-5.18)\end{array}$ & $\begin{array}{c}-8.955 * * * \\
(-3.17)\end{array}$ \\
\hline No. countries MNE operates & $\begin{array}{c}-1.914 * * * \\
(-9.10)\end{array}$ & & & \\
\hline PSentiment $\times$ No. countries MNE operates & $\begin{array}{c}0.754 * * * \\
(6.04)\end{array}$ & & & \\
\hline No. subsidiaries & & $\begin{array}{l}-0.104 * * \\
(-2.22)\end{array}$ & & \\
\hline PSentiment $\times$ No. subsidiaries & & $\begin{array}{c}0.156^{* * * *} \\
(3.82)\end{array}$ & & \\
\hline Foreign economies of scale & & & $\begin{array}{l}-6.375^{* * * *} \\
(-5.64)\end{array}$ & \\
\hline PSentiment $\times$ Foreign economies of scale & & & $\begin{array}{c}5.445 * * * \\
(9.04)\end{array}$ & \\
\hline Sub. country political polarization & & & & $\begin{array}{l}0.915 \\
(0.46)\end{array}$ \\
\hline PSentiment $\times$ Sub. country political polarization & & & & $\begin{array}{c}4.870 * * * \\
(2.80)\end{array}$ \\
\hline Relationship dummy & $\begin{array}{c}-6.473 * * * \\
(-3.27)\end{array}$ & $\begin{array}{c}-6.599 * * * \\
(-3.29)\end{array}$ & $\begin{array}{c}-6.372 * * * \\
(-3.26)\end{array}$ & $\begin{array}{c}-6.878 * * * \\
(-3.25)\end{array}$ \\
\hline Covenant dummy & $\begin{array}{c}13.974 * * * \\
(6.67)\end{array}$ & $\begin{array}{c}13.805^{* * * *} \\
(6.49)\end{array}$ & $\begin{array}{c}12.862 * * * \\
(6.08)\end{array}$ & $\begin{array}{l}11.618 * * * \\
(5.60)\end{array}$ \\
\hline Maturity & $\begin{array}{l}-0.259 \\
(-1.20)\end{array}$ & $\begin{array}{l}-0.26 \\
(-1.22)\end{array}$ & $\begin{array}{l}-0.251 \\
(-1.18)\end{array}$ & $\begin{array}{l}-0.195 \\
(-0.93)\end{array}$ \\
\hline Firm size & $\begin{array}{c}-15.807 * * * \\
(-13.24)\end{array}$ & $\begin{array}{l}-19.269 * * * \\
(-13.58)\end{array}$ & $\begin{array}{c}-19.436 * * * \\
(-15.46)\end{array}$ & $\begin{array}{c}-21.060 * * * \\
(-16.86)\end{array}$ \\
\hline NYSE & $\begin{array}{c}10.811 * * * \\
(2.70)\end{array}$ & $\begin{array}{l}8.367 * \\
(1.97)\end{array}$ & $\begin{array}{c}8.740 * * \\
(2.09)\end{array}$ & $\begin{array}{c}8.649 * * \\
(2.07)\end{array}$ \\
\hline Profitability & $\begin{array}{c}-76.893 * * * \\
(-8.08)\end{array}$ & $\begin{array}{c}-79.401 * * * \\
(-8.28)\end{array}$ & $\begin{array}{c}-83.594 * * * \\
(-8.34)\end{array}$ & $\begin{array}{c}-83.900 * * * \\
(-9.05)\end{array}$ \\
\hline MTB & $\begin{array}{c}-18.013 * * * \\
(-14.66)\end{array}$ & $\begin{array}{c}-18.770 * * * \\
(-14.51)\end{array}$ & $\begin{array}{c}-19.013 * * * \\
(-14.62)\end{array}$ & $\begin{array}{c}-18.085 * * * \\
(-14.62)\end{array}$ \\
\hline Bank size & $\begin{array}{l}-0.352 \\
(-0.70) \\
\end{array}$ & $\begin{array}{l}-0.267 \\
(-0.53) \\
\end{array}$ & $\begin{array}{c}-0.141 \\
(-0.29) \\
\end{array}$ & $\begin{array}{l}-0.293 \\
(-0.57) \\
\end{array}$ \\
\hline Observations & 9,552 & 9,552 & 9,552 & 9,461 \\
\hline Adjusted $\mathrm{R}^{2}$ & 0.547 & 0.542 & 0.546 & 0.538 \\
\hline Cluster & Bank & Bank & Bank & Bank \\
\hline Bank FE & $\sqrt{ }$ & $\sqrt{ }$ & $\sqrt{ }$ & $\sqrt{ }$ \\
\hline Year FE & $\sqrt{ }$ & $\sqrt{ }$ & $\sqrt{ }$ & $\sqrt{ }$ \\
\hline SIC3 FE & $\sqrt{ }$ & $\sqrt{ }$ & $\sqrt{ }$ & $\sqrt{ }$ \\
\hline Purpose FE & $\sqrt{ }$ & $\sqrt{ }$ & $\sqrt{ }$ & $\sqrt{ }$ \\
\hline Loan type FE & $\sqrt{ }$ & $\sqrt{ }$ & $\sqrt{ }$ & $\sqrt{ }$ \\
\hline
\end{tabular}




\section{Table 9}

Political sentiment and foreign operations controlling for boardroom characteristics.

The dependent variable is $A I S D$ - all-in-spread-drawn (bps), — defined as the sum of spread over LIBOR plus the facility fee. PSentiment denotes a firm's overall political sentiment and it is an index that is constructed by Hassan et al. (2019). This variable is standardized with zero mean and a standard deviation equal to one. Definitions of all variables along with their sources are in appendix table A1. Robust standard errors clustered by bank and t-statistics are reported in parentheses. Significance at the $1 \%$, $5 \%$, and $10 \%$ level is indicated by $* * *, * *$, and $*$, respectively.

\begin{tabular}{|c|c|c|c|c|}
\hline & (1) & $(2)$ & (3) & (4) \\
\hline PSentiment & $\begin{array}{c}-8.397 * * * \\
(-4.31)\end{array}$ & $\begin{array}{c}-5.894 * * * \\
(-3.65)\end{array}$ & $\begin{array}{c}-7.834 * * * \\
(-5.50)\end{array}$ & $\begin{array}{c}-9.254 * * * \\
(-3.44)\end{array}$ \\
\hline No. countries MNE operates & $\begin{array}{c}-1.975 * * * \\
(-9.15)\end{array}$ & & & \\
\hline PSentiment $\times$ No. countries MNE operates & $\begin{array}{c}0.713 * * * \\
(5.47)\end{array}$ & & & \\
\hline No. subsidiaries & & $\begin{array}{c}-0.095^{* *} \\
(-1.99)\end{array}$ & & \\
\hline PSentiment $\times$ No. subsidiaries & & $\begin{array}{c}0.146^{* * * *} \\
(3.59)\end{array}$ & & \\
\hline Foreign economies of scale & & & $\begin{array}{c}-6.260 * * * \\
(-5.10)\end{array}$ & \\
\hline PSentiment $\times$ Foreign economies of scale & & & $\begin{array}{c}5.594 * * * \\
(9.32)\end{array}$ & \\
\hline Sub. country political polarization & & & & $\begin{array}{l}0.744 \\
(0.38)\end{array}$ \\
\hline PSentiment $\times$ Sub. country political polarization & & & & $\begin{array}{c}4.699 * * * \\
(2.82)\end{array}$ \\
\hline Relationship dummy & $\begin{array}{c}-5.473 * * * \\
(-2.78)\end{array}$ & $\begin{array}{c}-5.654 * * * \\
(-2.84)\end{array}$ & $\begin{array}{c}-5.436 * * * \\
(-2.78)\end{array}$ & $\begin{array}{c}-5.729 * * * \\
(-2.73)\end{array}$ \\
\hline Covenant dummy & $\begin{array}{c}13.400^{* * * *} \\
\quad(6.78)\end{array}$ & $\begin{array}{c}13.230^{* * *} \\
\quad(6.55)\end{array}$ & $\begin{array}{c}12.266^{* * *} \\
(6.09)\end{array}$ & $\begin{array}{c}10.673 * * * \\
(5.59)\end{array}$ \\
\hline Maturity & $\begin{array}{l}-0.251 \\
(-1.18)\end{array}$ & $\begin{array}{r}-0.253 \\
(-1.21)\end{array}$ & $\begin{array}{r}-0.241 \\
(-1.16)\end{array}$ & $\begin{array}{l}-0.185 \\
(-0.90)\end{array}$ \\
\hline Firm size & $\begin{array}{c}-15.407 * * * \\
(-13.44)\end{array}$ & $\begin{array}{c}-19.087 * * * \\
(-13.57)\end{array}$ & $\begin{array}{c}-19.448 * * * \\
(-15.43)\end{array}$ & $\begin{array}{c}-21.060 * * * \\
(-16.65)\end{array}$ \\
\hline NYSE & $\begin{array}{c}11.668^{* * *} \\
(2.89)\end{array}$ & $\begin{array}{c}9.074^{* *} \\
(2.12)\end{array}$ & $\begin{array}{c}9.380^{* *} \\
(2.23)\end{array}$ & $\begin{array}{c}9.600^{* *} \\
(2.31)\end{array}$ \\
\hline Profitability & $\begin{array}{c}-75.377 * * * \\
(-7.88)\end{array}$ & $\begin{array}{c}-77.780 * * * \\
(-8.09)\end{array}$ & $\begin{array}{c}-81.678^{* * *} \\
(-8.17)\end{array}$ & $\begin{array}{c}-82.083^{* * *} \\
(-8.84)\end{array}$ \\
\hline MTB & $\begin{array}{c}-18.765^{* * *} \\
(-14.99)\end{array}$ & $\begin{array}{c}-19.512 * * * \\
(-14.67)\end{array}$ & $\begin{array}{c}-19.641^{* * *} \\
(-14.82)\end{array}$ & $\begin{array}{c}-19.116^{* * *} \\
(-15.04)\end{array}$ \\
\hline Bank size & $\begin{array}{l}-0.422 \\
(-0.84)\end{array}$ & $\begin{array}{l}-0.343 \\
(-0.69)\end{array}$ & $\begin{array}{l}-0.179 \\
(-0.37)\end{array}$ & $\begin{array}{l}-0.399 \\
(-0.78)\end{array}$ \\
\hline No. directors & $\begin{array}{l}-0.49 \\
(-0.91)\end{array}$ & $\begin{array}{l}-0.517 \\
(-0.98)\end{array}$ & $\begin{array}{l}0.041 \\
(0.07)\end{array}$ & $\begin{array}{l}-0.959^{*} \\
(-1.74)\end{array}$ \\
\hline Audit committee size & $\begin{array}{c}-3.511 * * * \\
(-3.49)\end{array}$ & $\begin{array}{c}-3.246^{* * *} \\
(-3.17)\end{array}$ & $\begin{array}{c}-4.229 * * * \\
(-4.14)\end{array}$ & $\begin{array}{c}-2.778 * * * \\
(-2.92)\end{array}$ \\
\hline No. independent directors & $\begin{array}{c}3.684 * * * \\
(4.01)\end{array}$ & $\begin{array}{c}3.228^{* * * *} \\
(3.57)\end{array}$ & $\begin{array}{c}2.473 * * * \\
(2.75)\end{array}$ & $\begin{array}{c}4.477 * * * \\
(4.83)\end{array}$ \\
\hline Mean directorship & $\begin{array}{c}2.636^{* * * *} \\
(3.90)\end{array}$ & $\begin{array}{c}2.464 * * * \\
(3.61)\end{array}$ & $\begin{array}{c}2.314 * * * \\
(3.44)\end{array}$ & $\begin{array}{c}3.881 * * * \\
(5.99)\end{array}$ \\
\hline Director's average age & $\begin{array}{c}-0.590^{*} \\
(-1.87) \\
\end{array}$ & $\begin{array}{c}-0.551^{*} \\
(-1.72) \\
\end{array}$ & $\begin{array}{l}-0.660^{*} \\
(-1.97) \\
\end{array}$ & $\begin{array}{c}-1.049 * * * \\
(-3.33) \\
\end{array}$ \\
\hline Observations & 9,525 & 9,525 & 9,525 & 9,434 \\
\hline Adjusted $\mathrm{R}^{2}$ & 0.548 & 0.543 & 0.547 & 0.541 \\
\hline Cluster & Bank & Bank & Bank & Bank \\
\hline Bank FE & $\sqrt{ }$ & $\sqrt{ }$ & $\sqrt{ }$ & $\sqrt{ }$ \\
\hline Year FE & $\sqrt{ }$ & $\sqrt{ }$ & $\sqrt{ }$ & $\sqrt{ }$ \\
\hline SIC3 FE & $\sqrt{ }$ & $\sqrt{ }$ & $\sqrt{ }$ & $\sqrt{ }$ \\
\hline Purpose FE & $\sqrt{ }$ & $\sqrt{ }$ & $\sqrt{ }$ & $\sqrt{ }$ \\
\hline Loan type FE & $\sqrt{ }$ & $\sqrt{ }$ & $\sqrt{ }$ & $\sqrt{ }$ \\
\hline
\end{tabular}




\section{Table 10}

Political sentiment and foreign operations excluding the top 3 lead arrangers.

The dependent variable is $A I S D$ - all-in-spread-drawn (bps), — defined as the sum of spread over LIBOR plus the facility fee. PSentiment denotes a firm's overall political sentiment and it is an index that is constructed by Hassan et al. (2019). This variable is standardized with zero mean and a standard deviation equal to one. Definitions of all variables along with their sources are in appendix table A1. Robust standard errors clustered by bank and t-statistics are reported in parentheses. Significance at the $1 \%, 5 \%$, and $10 \%$ level is indicated by $* * *, * *$, and *, respectively.

PSentiment

PSentiment

No. countries MNE operates

PSentiment $\times$ No. countries MNE operates

No. subsidiaries

PSentiment $\times$ No. subsidiaries

Foreign economies of scale

PSentiment $\times$ Foreign economies of scale

Sub. country political polarization

$$
\text { (1) }
$$

$-10.578 * *$

$(-4.76)$

$-1.622 * * *$

$(-5.79)$

$0.943 * * *$

(6.02)

(2)

$-7.508 * *$

$(-3.75)$

$403 * * *$

$(-3.82)$

(4)

$-7.310 * *$

$(-2.04)$

-0.106
$(-1.12)$
$0.242 * * *$
$(3.84)$

(3.84)

$-6.957 * * *$
$(-4.90)$
$4.861 * * *$

(5.34)

0.683

$(0.27)$

3.249

(1.65)

Relationship dummy

Covenant dummy

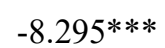

$(-3.84)$

$12.487 * * *$

(4.94)

Maturity

$-0.677 * * *$

$(-3.04)$

Firm size

$-17.126 * * *$

$(-8.66)$

$12.286 * * *$

(2.72)

NYSE

Profitability

$-73.715 * * *$

$(-5.73)$

MTB

Bank size

$-17.893 * * *$

$(-10.22)$

$-1.805^{* * *}$

$-8.224 * * *$

$(-3.67)$

$11.975^{* * *}$

(4.83)

$-0.669 * * *$

$(-3.01)$

$-19.788 * * *$

$(-8.87)$

$10.639 * *$

(2.29)

$-76.457 * * *$

$(-5.92)$

$-18.678^{* * *}$

(-10.13)

$-1.684 * * *$

$-7.814 * * *$

$(-3.50)$

11.570 ***

(4.55)

$-8.261^{* * *}$

$(-3.67)$

$11.698 * * *$

(4.61)

$-0.644 * * *$

$(-2.93)$

$-19.410 * * *$

$(-10.86)$

$11.502 * *$

(2.54)

$-80.282 * * *$

$(-6.10)$

$-0.662 * * *$

$(-3.06)$

$-20.952 * * *$

(-11.09)

$10.602 * *$

(2.34)

$-79.325^{* * *}$

(-6.03)

$-18.953 * * *$

$-18.548 * * *$

$(-10.39)$

$(-10.71)$

$-1.452 * * *$

$-1.656 * * *$

(-3.20)

$(-2.93)$

6,614

0.549

$(-2.64)$

$(-2.82)$

Observations

6,614
0.552

Bank

Bank

Bank FE

Year FE

SIC3 FE

Purpose FE

Loan type FE

\begin{tabular}{cccc} 
Bank & Bank & Bank & Bank \\
$\sqrt{ }$ & $\sqrt{ }$ & $\sqrt{ }$ & $\sqrt{ }$ \\
$\sqrt{ }$ & $\sqrt{ }$ & $\sqrt{ }$ & $\sqrt{ }$ \\
$\sqrt{ }$ & $\sqrt{ }$ & $\sqrt{ }$ & $\sqrt{ }$ \\
$\sqrt{ }$ & $\sqrt{ }$ & $\sqrt{ }$ & $\sqrt{ }$ \\
$\sqrt{ }$ & $\sqrt{ }$ & $\sqrt{ }$ & $\sqrt{ }$ \\
\hline
\end{tabular}


Table 11

Political sentiment and foreign operations: controlling for a company's credit rating.

The dependent variable is $A I S D$-all-in-spread-drawn (bps), — defined as the sum of spread over LIBOR plus the facility fee. PSentiment denotes a firm's overall political sentiment and it is an index that is constructed by Hassan et al. (2019). This variable is standardized with zero mean and a standard deviation equal to one. Definitions of all variables along with their sources are in appendix table A1. Robust standard errors clustered by bank and t-statistics are reported in parentheses. Significance at the $1 \%, 5 \%$, and $10 \%$ level is indicated by $* * *, * *$, and $*$, respectively.

\begin{tabular}{|c|c|c|c|c|}
\hline & $\overline{~(1) ~}$ & (2) & (3) & (4) \\
\hline PSentiment & $\begin{array}{c}-8.617 * * * \\
(-4.10)\end{array}$ & $\begin{array}{c}-5.788 * * * \\
(-3.37)\end{array}$ & $\begin{array}{c}-7.842 * * * \\
(-5.23)\end{array}$ & $\begin{array}{c}-8.462 * * * \\
(-2.95)\end{array}$ \\
\hline Company rating & $\begin{array}{c}2.215^{* * * *} \\
(5.10)\end{array}$ & $\begin{array}{c}2.337 * * * \\
(5.20)\end{array}$ & $\begin{array}{c}2.365 * * * \\
(5.42)\end{array}$ & $\begin{array}{c}2.124 * * * \\
(4.79)\end{array}$ \\
\hline No. countries MNE operates & $\begin{array}{c}-1.826 * * * \\
(-8.97)\end{array}$ & & & \\
\hline PSentiment $\times$ No. countries MNE operates & $\begin{array}{c}0.737 * * * \\
(5.53)\end{array}$ & & & \\
\hline No. subsidiaries & & $\begin{array}{c}-0.097 * * \\
(-1.98)\end{array}$ & & \\
\hline PSentiment $\times$ No. subsidiaries & & $\begin{array}{c}0.147 * * * \\
(3.57)\end{array}$ & & \\
\hline Foreign economies of scale & & & $\begin{array}{c}-6.319 * * * \\
(-5.67)\end{array}$ & \\
\hline PSentiment $\times$ Foreign economies of scale & & & $\begin{array}{c}5.699 * * * \\
(8.36)\end{array}$ & \\
\hline Sub. country political polarization & & & & $\begin{array}{l}0.334 \\
(0.16)\end{array}$ \\
\hline PSentiment $\times$ Sub. country political polarization & & & & $\begin{array}{l}4.518^{* * *} \\
(2.48)\end{array}$ \\
\hline Relationship dummy & $\begin{array}{c}-7.265^{* * *} \\
(-3.29)\end{array}$ & $\begin{array}{c}-7.257 * * * \\
(-3.28)\end{array}$ & $\begin{array}{c}-7.038 * * * \\
(-3.25)\end{array}$ & $\begin{array}{c}-7.608 * * * \\
(-3.30)\end{array}$ \\
\hline Covenant dummy & $\begin{array}{c}15.021 * * * \\
(7.36)\end{array}$ & $\begin{array}{c}14.652 * * * \\
(7.20)\end{array}$ & $\begin{array}{c}13.653^{* * * *} \\
(6.82)\end{array}$ & $\begin{array}{c}12.325 * * * \\
(6.00)\end{array}$ \\
\hline Maturity & $\begin{array}{l}-0.173 \\
(-0.79)\end{array}$ & $\begin{array}{l}-0.167 \\
(-0.77)\end{array}$ & $\begin{array}{l}-0.156 \\
(-0.72)\end{array}$ & $\begin{array}{l}-0.109 \\
(-0.52)\end{array}$ \\
\hline Firm size & $\begin{array}{c}-11.725^{* * *} \\
(-8.75)\end{array}$ & $\begin{array}{c}-14.767 * * * \\
(-9.77)\end{array}$ & $\begin{array}{c}-14.780 * * * \\
(-10.48)\end{array}$ & $\begin{array}{c}-16.893 * * * \\
(-12.21)\end{array}$ \\
\hline NYSE & $\begin{array}{c}12.812 * * * \\
(3.28)\end{array}$ & $\begin{array}{c}10.287^{* *} \\
(2.50)\end{array}$ & $\begin{array}{c}10.807 * * * \\
(2.70)\end{array}$ & $\begin{array}{c}10.666^{* * *} \\
(2.63)\end{array}$ \\
\hline Profitability & $\begin{array}{c}-66.940 * * * \\
(-7.28)\end{array}$ & $\begin{array}{c}-68.850 * * * \\
(-7.23)\end{array}$ & $\begin{array}{c}-74.297 * * * \\
(-7.49)\end{array}$ & $\begin{array}{c}-72.843^{* * *} \\
(-8.05)\end{array}$ \\
\hline MTB & $\begin{array}{c}-22.344 * * * \\
(-13.25)\end{array}$ & $\begin{array}{c}-23.187 * * * \\
(-13.09)\end{array}$ & $\begin{array}{c}-23.460 * * * \\
(-13.45)\end{array}$ & $\begin{array}{c}-22.125^{* * *} \\
(-12.81)\end{array}$ \\
\hline Bank size & $\begin{array}{c}0.075 \\
(0.12)\end{array}$ & $\begin{array}{l}0.238 \\
(0.40)\end{array}$ & $\begin{array}{l}0.45 \\
(0.75) \\
\end{array}$ & $\begin{array}{l}0.132 \\
(0.22) \\
\end{array}$ \\
\hline Observations & 8,917 & 8,917 & 8,924 & 8,839 \\
\hline Adjusted $\mathrm{R}^{2}$ & 0.562 & 0.558 & 0.562 & 0.552 \\
\hline Cluster & Bank & Bank & Bank & Bank \\
\hline Bank FE & $\sqrt{ }$ & $\sqrt{ }$ & $\sqrt{ }$ & $\sqrt{ }$ \\
\hline Year FE & $\sqrt{ }$ & $\sqrt{ }$ & $\sqrt{ }$ & $\sqrt{ }$ \\
\hline SIC3 FE & $\sqrt{ }$ & $\sqrt{ }$ & $\sqrt{ }$ & $\sqrt{ }$ \\
\hline Purpose FE & $\sqrt{ }$ & $\sqrt{ }$ & $\sqrt{ }$ & $\sqrt{ }$ \\
\hline Loan type FE & $\sqrt{ }$ & $\sqrt{ }$ & $\sqrt{ }$ & $\sqrt{ }$ \\
\hline
\end{tabular}




\section{Table 12}

Political sentiment and foreign operations: controlling for realized volatility.

The dependent variable is $A I S D$-all-in-spread-drawn (bps), —defined as the sum of spread over LIBOR plus the facility fee. PSentiment denotes a firm's overall political sentiment and it is an index that is constructed by Hassan et al. (2019). This variable is standardized with zero mean and a standard deviation equal to one. Definitions of all variables along with their sources are in appendix table A1. Robust standard errors clustered by bank and t-statistics are reported in parentheses. Significance at the $1 \%, 5 \%$, and $10 \%$ level is indicated by $* * *, * *$, and *, respectively.

\begin{tabular}{|c|c|c|c|c|}
\hline & (1) & $\overline{(2)}$ & (3) & (4) \\
\hline PSentiment & $\begin{array}{c}-6.396^{* * *} \\
(-3.11)\end{array}$ & $\begin{array}{c}-3.918^{* *} \\
(-2.37)\end{array}$ & $\begin{array}{c}-5.579 * * * \\
(-3.70)\end{array}$ & $\begin{array}{l}-0.855 \\
(-0.25)\end{array}$ \\
\hline Realized volatility & $\begin{array}{c}128.567^{* * * *} \\
(9.17)\end{array}$ & $\begin{array}{c}129.717 * * * \\
(9.07)\end{array}$ & $\begin{array}{c}132.442 * * * \\
(9.26)\end{array}$ & $\begin{array}{c}118.679 * * * \\
(7.89)\end{array}$ \\
\hline No. countries MNE operates & $\begin{array}{c}-1.817 * * * \\
(-9.46)\end{array}$ & & & \\
\hline Psentiment $\times$ No. countries MNE operates & $\begin{array}{c}0.666^{* * *} \\
(5.04)\end{array}$ & & & \\
\hline No. subsidiaries & & $\begin{array}{c}-0.231 * * * \\
(-4.47)\end{array}$ & & \\
\hline Psentiment $\times$ No. subsidiaries & & $\begin{array}{c}0.153^{* * *} * \\
(3.88)\end{array}$ & & \\
\hline Foreign economies of scale & & & $\begin{array}{c}-5.215 * * * \\
(-4.67)\end{array}$ & \\
\hline PSentiment $\times$ Foreign economies of scale & & & $\begin{array}{c}4.408 * * * \\
(6.10)\end{array}$ & \\
\hline Sub. country political polarization & & & & $\begin{array}{c}2.523 \\
(1.15)\end{array}$ \\
\hline PSentiment $\times$ Sub. country political polarization & & & & $\begin{array}{l}-0.084 \\
(-0.04)\end{array}$ \\
\hline Relationship dummy & $\begin{array}{c}-6.010 * * * \\
(-3.21)\end{array}$ & $\begin{array}{c}-6.378 * * * \\
(-3.36)\end{array}$ & $\begin{array}{c}-6.891 * * * \\
(-3.46)\end{array}$ & $\begin{array}{c}-6.788 * * * \\
(-3.40)\end{array}$ \\
\hline Covenant dummy & $\begin{array}{c}9.941 * * * \\
(5.12)\end{array}$ & $\begin{array}{c}9.320 * * * \\
(4.88)\end{array}$ & $\begin{array}{c}8.194 * * * \\
(4.26)\end{array}$ & $\begin{array}{c}8.042 * * * \\
(4.38)\end{array}$ \\
\hline Maturity & $\begin{array}{l}0.029 \\
(0.11)\end{array}$ & $\begin{array}{c}0.02 \\
(0.08)\end{array}$ & $\begin{array}{l}-0.093 \\
(-0.54)\end{array}$ & $\begin{array}{l}0.09 \\
(0.37)\end{array}$ \\
\hline Firm size & $\begin{array}{c}-14.690 * * * \\
(-10.21)\end{array}$ & $\begin{array}{c}-17.065^{* * *} \\
(-11.32)\end{array}$ & $\begin{array}{c}-17.820 * * * \\
(-12.26)\end{array}$ & $\begin{array}{c}-20.186^{* * *} \\
(-14.56)\end{array}$ \\
\hline NYSE & $\begin{array}{c}14.465^{* * *} \\
(3.46)\end{array}$ & $\begin{array}{c}12.513^{* * *} * \\
(2.91)\end{array}$ & $\begin{array}{c}10.671^{* *} \\
(2.28)\end{array}$ & $\begin{array}{c}12.331^{* *} \\
(2.54)\end{array}$ \\
\hline Profitability & $\begin{array}{c}-66.361^{* * *} \\
(-7.91)\end{array}$ & $\begin{array}{c}-68.402^{* * *} \\
(-8.16)\end{array}$ & $\begin{array}{c}-71.237 * * * \\
(-8.46)\end{array}$ & $\begin{array}{c}-73.501 * * * \\
(-8.33)\end{array}$ \\
\hline MTB & $\begin{array}{c}-14.719 * * * \\
(-10.90)\end{array}$ & $\begin{array}{c}-15.258 * * * \\
(-11.01)\end{array}$ & $\begin{array}{c}-15.683 * * * \\
(-10.38)\end{array}$ & $\begin{array}{c}-15.112 * * * \\
(-13.04)\end{array}$ \\
\hline Bank size & $\begin{array}{l}-0.709 \\
(-1.35) \\
\end{array}$ & $\begin{array}{l}-0.645 \\
(-1.21) \\
\end{array}$ & $\begin{array}{r}-0.569 \\
(-1.18) \\
\end{array}$ & $\begin{array}{l}-0.657 \\
(-1.21) \\
\end{array}$ \\
\hline Observations & 7,768 & 7,768 & 7,769 & 7,681 \\
\hline Adjusted $\mathrm{R}^{2}$ & 0.586 & 0.582 & 0.585 & 0.571 \\
\hline Cluster & Bank & Bank & Bank & Bank \\
\hline Bank FE & $\sqrt{ }$ & $\sqrt{ }$ & $\sqrt{ }$ & $\sqrt{ }$ \\
\hline Year FE & $\sqrt{ }$ & $\sqrt{ }$ & $\sqrt{ }$ & $\sqrt{ }$ \\
\hline SIC3 FE & $\sqrt{ }$ & $\sqrt{ }$ & $\sqrt{ }$ & $\sqrt{ }$ \\
\hline Purpose FE & $\sqrt{ }$ & $\sqrt{ }$ & $\sqrt{ }$ & $\sqrt{ }$ \\
\hline Loan type FE & $\sqrt{ }$ & $\sqrt{ }$ & $\sqrt{ }$ & $\sqrt{ }$ \\
\hline
\end{tabular}




\section{Table 13}

Political sentiment and foreign operations: controlling for implied volatility.

The dependent variable is $A I S D$-all-in-spread-drawn (bps), — defined as the sum of spread over LIBOR plus the facility fee. PSentiment denotes a firm's overall political sentiment and it is an index that is constructed by Hassan et al. (2019). This variable is standardized with zero mean and a standard deviation equal to one. Definitions of all variables along with their sources are in appendix table A1. Robust standard errors clustered by bank and t-statistics are reported in parentheses. Significance at the $1 \%, 5 \%$, and $10 \%$ level is indicated by $* * *, * *$, and *, respectively.

\begin{tabular}{|c|c|c|c|c|}
\hline & (1) & (2) & (3) & (4) \\
\hline PSentiment & $\begin{array}{c}-8.084 * * * \\
(-4.03)\end{array}$ & $\begin{array}{c}-5.655^{* * * *} \\
(-3.51)\end{array}$ & $\begin{array}{c}-7.477 * * * \\
(-4.88)\end{array}$ & $\begin{array}{l}-2.717 \\
(-0.85)\end{array}$ \\
\hline Implied volatility & $\begin{array}{c}207.036^{* * *} \\
(10.53)\end{array}$ & $\begin{array}{c}210.002 * * * \\
(10.44)\end{array}$ & $\begin{array}{c}219.693 * * * \\
(10.31)\end{array}$ & $\begin{array}{c}195.450 * * * \\
(8.96)\end{array}$ \\
\hline No. countries MNE operates & $\begin{array}{c}-1.562 * * * \\
(-7.82)\end{array}$ & & & \\
\hline PSentiment $\times$ No. countries MNE operates & $\begin{array}{c}0.703 * * * \\
(5.39)\end{array}$ & & & \\
\hline No. subsidiaries & & $\begin{array}{c}-0.167 * * * \\
(-3.55)\end{array}$ & & \\
\hline PSentiment $\times$ No. subsidiaries & & $\begin{array}{c}0.179 * * * \\
(4.67)\end{array}$ & & \\
\hline Foreign economies of scale & & & $\begin{array}{c}-6.992 * * * \\
(-7.10)\end{array}$ & \\
\hline PSentiment $\times$ Foreign economies of scale & & & $\begin{array}{c}5.024 * * * \\
(7.21)\end{array}$ & \\
\hline Sub. country political polarization & & & & $\begin{array}{l}1.619 \\
(0.79)\end{array}$ \\
\hline PSentiment $\times$ Sub. country political polarization & & & & $\begin{array}{l}0.562 \\
(0.26)\end{array}$ \\
\hline Relationship dummy & $\begin{array}{c}-4.423 * * \\
(-2.33)\end{array}$ & $\begin{array}{c}-4.638 * * \\
(-2.42)\end{array}$ & $\begin{array}{c}-5.233 * * * \\
(-2.66)\end{array}$ & $\begin{array}{l}-5.129 * * \\
(-2.59)\end{array}$ \\
\hline Covenant dummy & $\begin{array}{c}11.926^{* * * *} \\
(6.06)\end{array}$ & $\begin{array}{c}11.367 * * * \\
(5.82)\end{array}$ & $\begin{array}{c}9.965 * * * \\
(4.41)\end{array}$ & $\begin{array}{c}10.078 * * * \\
\quad(4.76)\end{array}$ \\
\hline Maturity & $\begin{array}{l}-0.217 \\
(-0.90)\end{array}$ & $\begin{array}{l}-0.225 \\
(-0.94)\end{array}$ & $\begin{array}{c}-0.330 * * \\
(-2.16)\end{array}$ & $\begin{array}{l}-0.117 \\
(-0.51)\end{array}$ \\
\hline Firm size & $\begin{array}{c}-12.844 * * * \\
(-9.53)\end{array}$ & $\begin{array}{c}-15.104 * * * \\
(-11.43)\end{array}$ & $\begin{array}{c}-15.031 * * * \\
(-12.23)\end{array}$ & $\begin{array}{c}-17.737 * * * \\
(-15.23)\end{array}$ \\
\hline NYSE & $\begin{array}{c}16.221^{* * * *} \\
(4.03)\end{array}$ & $\begin{array}{c}14.424 * * * \\
\quad(3.56)\end{array}$ & $\begin{array}{c}13.236^{* * * *} \\
(3.06)\end{array}$ & $\begin{array}{c}15.220 * * * \\
(3.33)\end{array}$ \\
\hline Profitability & $\begin{array}{c}-63.024 * * * \\
(-7.43)\end{array}$ & $\begin{array}{c}-64.421^{* * *} \\
(-7.64)\end{array}$ & $\begin{array}{c}-67.837 * * * \\
(-8.25)\end{array}$ & $\begin{array}{c}-70.014 * * * \\
(-7.80)\end{array}$ \\
\hline MTB & $\begin{array}{c}-12.531 * * * \\
(-10.61)\end{array}$ & $\begin{array}{c}-13.000 * * * \\
(-10.81)\end{array}$ & $\begin{array}{c}-13.248 * * * \\
(-10.12)\end{array}$ & $\begin{array}{c}-12.860 * * * \\
(-12.29)\end{array}$ \\
\hline Bank size & $\begin{array}{c}-0.952 * * \\
(-2.05) \\
\end{array}$ & $\begin{array}{c}-0.887 * \\
(-1.92) \\
\end{array}$ & $\begin{array}{l}-0.766^{*} \\
(-1.89) \\
\end{array}$ & $\begin{array}{l}-0.773 \\
(-1.62) \\
\end{array}$ \\
\hline Observations & 7,577 & 7,577 & 7,578 & 7,490 \\
\hline Adjusted $\mathrm{R}^{2}$ & 0.594 & 0.592 & 0.597 & 0.58 \\
\hline Cluster & Bank & Bank & Bank & Bank \\
\hline Bank FE & $\sqrt{ }$ & $\sqrt{ }$ & $\sqrt{ }$ & $\sqrt{ }$ \\
\hline Year FE & $\sqrt{ }$ & $\sqrt{ }$ & $\sqrt{ }$ & $\sqrt{ }$ \\
\hline SIC3 FE & $\sqrt{ }$ & $\sqrt{ }$ & $\sqrt{ }$ & $\sqrt{ }$ \\
\hline Purpose FE & $\sqrt{ }$ & $\sqrt{ }$ & $\sqrt{ }$ & $\sqrt{ }$ \\
\hline Loan type FE & $\sqrt{ }$ & $\sqrt{ }$ & $\sqrt{ }$ & $\sqrt{ }$ \\
\hline
\end{tabular}




\section{Table 14}

Two-stage least squares estimations.

The dependent variable is $A I S D$-all-in-spread-drawn (bps), — defined as the sum of spread over LIBOR plus the facility fee. PSentiment denotes a firm's overall political sentiment and it is an index that is constructed by Hassan et al. (2019). This variable is standardized with zero mean and a standard deviation equal to one. Definitions of all variables along with their sources are in appendix table A1. Robust standard errors clustered by bank and t-statistics are reported in parentheses. Significance at the $1 \%, 5 \%$, and $10 \%$ level is indicated by $* * *, * *$, and $*$, respectively.

\begin{tabular}{|c|c|c|c|c|c|c|c|c|}
\hline & \multicolumn{4}{|c|}{ Instrument: external conflict } & \multicolumn{4}{|c|}{ Instrument: 5-year average industry PSentiment (SIC3) } \\
\hline & Second-stage & First-stage & Second-stage & First-stage & Second-stage & First-stage & Second-stage & First-stage \\
\hline & (1) & (2) & (3) & (4) & (5) & (6) & (7) & (8) \\
\hline PSentiment (fitted) & $\begin{array}{c}-120.836 * * * \\
(-5.76)\end{array}$ & & $\begin{array}{c}-104.189 * * * \\
(-5.88)\end{array}$ & & $\begin{array}{c}-11.747 * * * \\
(-6.57)\end{array}$ & & $\begin{array}{c}-11.148 * * * \\
(-8.07)\end{array}$ & \\
\hline Instrument & & $\begin{array}{c}0.112 * * * \\
(6.84)\end{array}$ & & $\begin{array}{c}0.109 * * * \\
(7.07)\end{array}$ & & $\begin{array}{c}6.68 \mathrm{E}-04 * * * \\
(33.96)\end{array}$ & & $\begin{array}{c}6.71 \mathrm{E}-04 * * * \\
(33.78)\end{array}$ \\
\hline Relationship dummy & $\begin{array}{c}-13.461 * * * \\
(-4.75)\end{array}$ & $\begin{array}{c}-0.1 \\
(-0.6)\end{array}$ & $\begin{array}{c}-11.879 * * * \\
(-4.51)\end{array}$ & $\begin{array}{c}-0.046^{* * *} \\
(-2.8)\end{array}$ & $\begin{array}{c}-11.577 * * * \\
(-10.85)\end{array}$ & $\begin{array}{l}-0.014 \\
(-1.34)\end{array}$ & $\begin{array}{c}-3.083^{* * *} \\
(-3.70)\end{array}$ & $\begin{array}{c}-0.021^{* *} \\
(-2.06)\end{array}$ \\
\hline Covenant dummy & $\begin{array}{l}2.881 \\
(0.97)\end{array}$ & $\begin{array}{l}-0.018 \\
(-0.94)\end{array}$ & $\begin{array}{c}7.738 * * * \\
(3.42)\end{array}$ & $\begin{array}{l}-0.003 \\
(-0.14)\end{array}$ & $\begin{array}{c}10.960 * * * \\
(6.80)\end{array}$ & $\begin{array}{l}-0.015 \\
(-1.58)\end{array}$ & $\begin{array}{c}10.949 * * * \\
(8.91)\end{array}$ & $\begin{array}{c}-0.017^{*} \\
(-1.75)\end{array}$ \\
\hline Maturity & $\begin{array}{c}0.552 * * * \\
(4.70)\end{array}$ & $\begin{array}{l}-0.001 \\
(-1.08)\end{array}$ & $\begin{array}{l}0.331 \\
(1.43)\end{array}$ & $\begin{array}{l}0.001 \\
(1.58)\end{array}$ & $\begin{array}{l}0.428^{* * * *} \\
(7.40)\end{array}$ & $\begin{array}{l}-0.000 \\
(-0.19)\end{array}$ & $\begin{array}{c}-0.346^{* * *} \\
(-3.99)\end{array}$ & $\begin{array}{c}0.001^{* *} \\
(2.03)\end{array}$ \\
\hline Firm size & $\begin{array}{c}-16.021 * * * \\
(-7.49)\end{array}$ & $\begin{array}{c}0.035 * * * \\
(2.63)\end{array}$ & $\begin{array}{c}-14.988 * * * \\
(-8.61)\end{array}$ & $\begin{array}{c}0.042 * * * \\
(3.57)\end{array}$ & $\begin{array}{c}-22.270 * * * \\
(-28.47)\end{array}$ & $\begin{array}{c}0.031 * * * \\
(5.53)\end{array}$ & $\begin{array}{c}-19.211 * * * \\
(-28.73)\end{array}$ & $\begin{array}{c}0.030 * * * \\
(5.13)\end{array}$ \\
\hline NYSE & $\begin{array}{c}-12.638^{*} \\
(-1.80)\end{array}$ & $\begin{array}{c}-0.121 * * * \\
(-2.84)\end{array}$ & $\begin{array}{l}-5.713 \\
(-0.95)\end{array}$ & $\begin{array}{c}-0.087^{*} \\
(-1.87)\end{array}$ & $\begin{array}{l}-4.981 \\
(-1.64)\end{array}$ & $\begin{array}{l}-0.003 \\
(-0.21)\end{array}$ & $\begin{array}{l}-1.894 \\
(-0.77)\end{array}$ & $\begin{array}{l}-0.003 \\
(-0.19)\end{array}$ \\
\hline Profitability & $\begin{array}{c}-110.300^{* * * *} \\
(-6.21)\end{array}$ & $\begin{array}{l}-0.087 \\
(-0.83)\end{array}$ & $\begin{array}{c}-80.740 * * * \\
(-5.81)\end{array}$ & $\begin{array}{l}-0.149 \\
(-1.44)\end{array}$ & $\begin{array}{c}-103.261 * * * \\
(-12.37)\end{array}$ & $\begin{array}{l}0.037 \\
(0.67)\end{array}$ & $\begin{array}{c}-87.151^{* * * *} \\
(-12.49)\end{array}$ & $\begin{array}{r}0.024 \\
(0.44)\end{array}$ \\
\hline MTB & $\begin{array}{l}-4.039 \\
(-1.30)\end{array}$ & $\begin{array}{c}0.085 * * * \\
(5.58)\end{array}$ & $\begin{array}{c}-8.427^{* * * *} \\
(-3.68)\end{array}$ & $\begin{array}{c}0.075^{* * *} * \\
(4.33)\end{array}$ & $\begin{array}{c}-19.000 * * * \\
(-21.50)\end{array}$ & $\begin{array}{c}0.100 * * * \\
(10.04)\end{array}$ & $\begin{array}{c}-16.877 * * * \\
(-18.85)\end{array}$ & $\begin{array}{c}0.103 * * * \\
(11.01)\end{array}$ \\
\hline Bank size & $\begin{array}{c}-3.779 * * * \\
(-3.61) \\
\end{array}$ & $\begin{array}{c}-0.025^{* * *} \\
(-4.65) \\
\end{array}$ & $\begin{array}{c}-3.503 * * * \\
(-3.44) \\
\end{array}$ & $\begin{array}{c}-0.030^{* * * *} \\
(-5.08) \\
\end{array}$ & $\begin{array}{c}-1.462 * * * \\
(-4.31)\end{array}$ & $\begin{array}{c}-0.012 * * \\
(-2.56) \\
\end{array}$ & $\begin{array}{c}-0.905^{* * * *} \\
(-2.66) \\
\end{array}$ & $\begin{array}{c}-0.013 * * * \\
(-2.58)\end{array}$ \\
\hline Observations & \multicolumn{2}{|c|}{9,238} & \multicolumn{2}{|c|}{8,925} & \multicolumn{2}{|c|}{35,043} & \multicolumn{2}{|c|}{34,569} \\
\hline Cragg-Donald Wald F statistic & \multicolumn{2}{|c|}{82.053} & \multirow{2}{*}{\multicolumn{2}{|c|}{$\begin{array}{l}76.606 \\
49.958\end{array}$}} & \multirow{2}{*}{\multicolumn{2}{|c|}{$\begin{array}{c}5,256.596 \\
1.153 .238\end{array}$}} & \multicolumn{2}{|c|}{$5,203.428$} \\
\hline Kleibergen-Paap rk Wald F statistic & \multirow{2}{*}{\multicolumn{2}{|c|}{46.732}} & & 49.958 & & $1,153.238$ & \multicolumn{2}{|c|}{$1,140.931$} \\
\hline Stock-Yogo critical values & & 16.38 & \multicolumn{2}{|c|}{16.38} & \multicolumn{2}{|c|}{16.38} & \multicolumn{2}{|c|}{16.38} \\
\hline Cluster & \multicolumn{2}{|c|}{ Bank } & \multicolumn{2}{|c|}{ Bank } & \multicolumn{2}{|c|}{ Bank } & \multicolumn{2}{|c|}{ Bank } \\
\hline Bank FE & \multicolumn{2}{|c|}{$\sqrt{ }$} & \multicolumn{2}{|c|}{$\sqrt{ }$} & \multicolumn{2}{|c|}{$\sqrt{ }$} & \multicolumn{2}{|c|}{$\sqrt{ }$} \\
\hline Year FE & \multicolumn{2}{|c|}{$\sqrt{ }$} & \multicolumn{2}{|c|}{$\sqrt{ }$} & \multicolumn{2}{|c|}{$\sqrt{ }$} & \multicolumn{2}{|c|}{$\sqrt{ }$} \\
\hline SIC3 FE & \multicolumn{2}{|c|}{$\sqrt{ }$} & \multicolumn{2}{|c|}{$\sqrt{ }$} & \multicolumn{2}{|c|}{$\sqrt{ }$} & r & \\
\hline Purpose FE & . & & & & & & & \\
\hline Loan type FE & - & & & & & & tra & \\
\hline
\end{tabular}




\section{Table 15}

Main models using the total cost of borrowing as a dependent variable.

The dependent variable is the total cost of borrowing calculated according to Berg et al. (2016). All models include the firm and bank controls presented in the specifications of the main text. Definitions of all variables along with their sources are in appendix table A1. Robust standard errors clustered by bank and $t$-statistics are reported in parentheses. Significance at the $1 \%, 5 \%$, and $10 \%$ level is indicated by ***,**, and *, respectively.

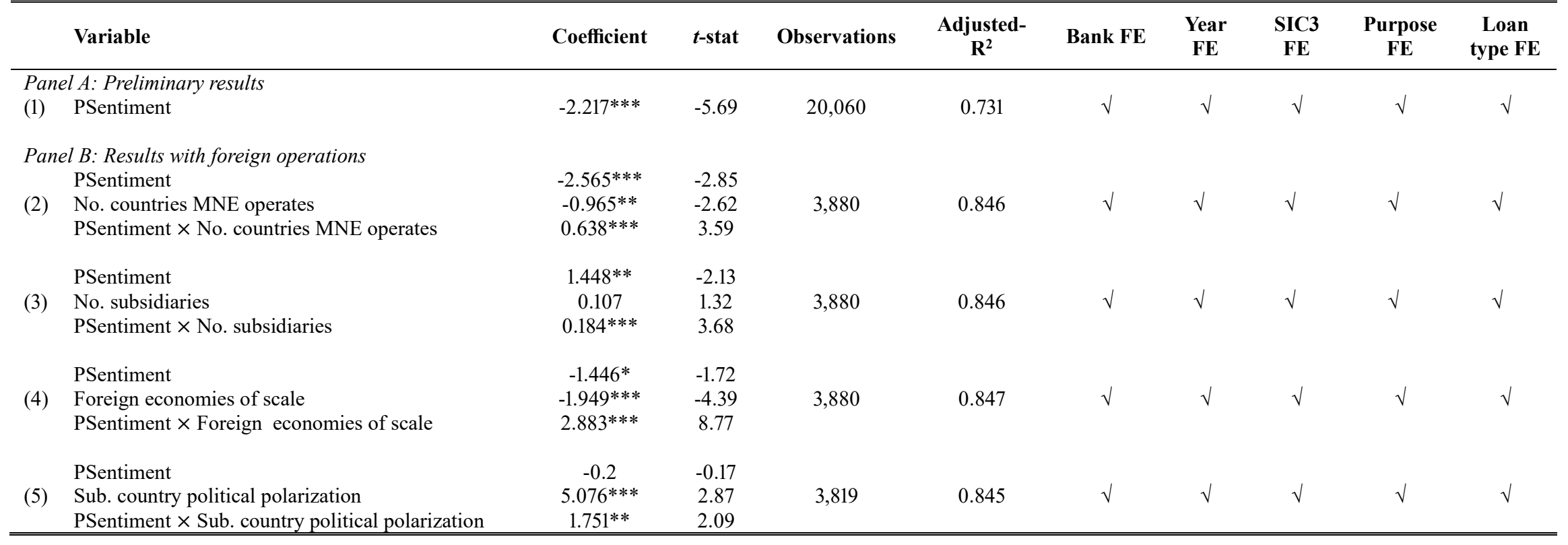


Table A1

Description of variables

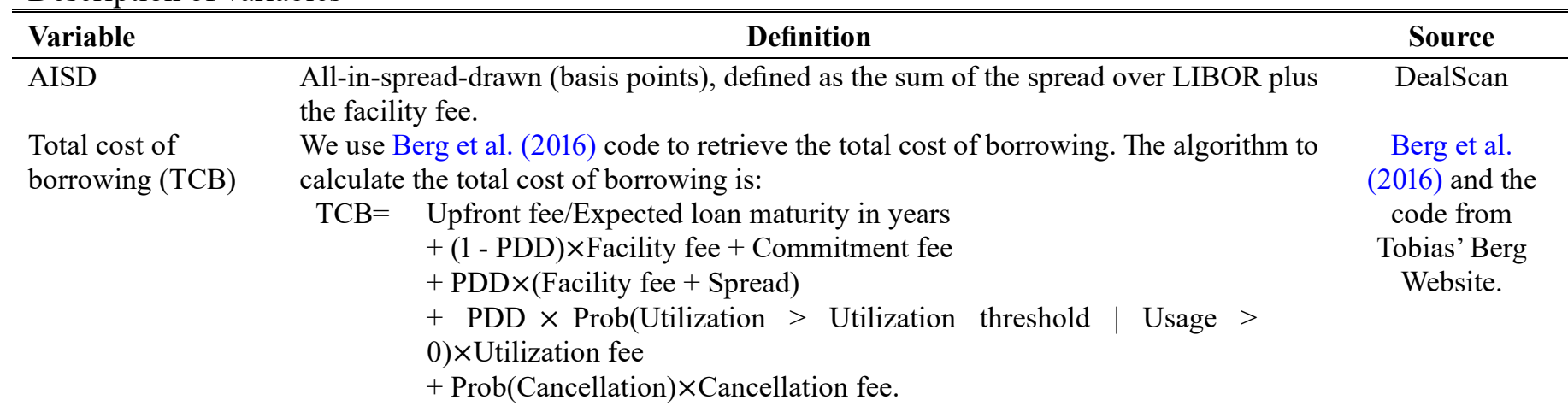

PSentiment This is the standardized value of the political sentiment of Hassan et al. (2019).

Hassan et al.

(2019)

Facility amount The loan (facility) amount in M\$ weighted by the bank's share.

DealScan

DealScan

Financial covenants The total number of financial covenants in the loan contract.
Relationship dummy Dummy equal to 1 if the bank lent to the same borrower in the five years before the current loan, 0 otherwise.

Covenant dummy Dummy equal to 1 if the loan has covenants, 0 otherwise.

Own calculation

Maturity

Loan duration in months.

Firm size

Firm's natural logarithm of total assets.

NYSE

Profitability

Dummy equal to 1 if the firm is listed on the New York Stock Exchange, 0 otherwise.

Tobin's Q (MTB)

The ratio of pretax profits to total assets.

The natural logarithm of market-to-book value.

Company rating Company $\mathrm{S} \& \mathrm{P}$ credit rating. Higher values indicate lower rating.

Bank size Bank's natural logarithm of total assets.

Board size The total number of directors in a board.

Audit committee size The number of directors who participate in audit committee.

No. directors The number of independent non-executive (external) directors with functional audit experience in the board.

Mean directorship The mean number of directorships held by the directors of a board.

Directors' average The mean age of the directors in a board.

Dealscan

Dealscan

Compustat

Compustat

Compustat

Compustat

Compustat

Call Reports

BoardEx

BoardEx

BoardEx

BoardEx

BoardEx

age

No. countries MNE This variable indicates the number of countries in which a parent company has multinational enterprises. For example, if an American parent company has subsidiaries in five countries, this variable equals 5.

Lead bank

Dummy equal to 1 if the bank is acting as a mandated arranger, arranger, lead manager or agent, $0 \mathrm{o} / \mathrm{w}$.

Top 3 bank

Dummy equal to 1 if lead arranger is one of the top 3 arrangers, namely Bank of America, Citigroup, or JPMorgan Chase, 0 o/w.

No. subsidiaries

This variable indicates the number of foreign subsidiaries of a parent company.

Foreign economies

of scale

This is the weighted ratio of subsidiary companies in the same industry as the parent company in a year.

Sub. country

political

polarization

With party orientations taking values one if Right, two if Center, and three if Left, country-level polarization measures "the maximum difference between the chief executive's party's values and the values of the three largest government parties and the largest opposition party." In our database, for each parent company and year, subsidiary country political polarization is the average value of the political polarization index, measured in the subsidiary country and weighted by the number of subsidiaries in that specific country.

External conflict This measure assesses the risk an incumbent government faces from both internal and external pressures. External pressures could affect foreign operations markedly through restrictions on operations, among others. Higher values of this variable indicate that a country is in a better standing from external conflict threat.

(continued on next page) 
(Table Al continued from previous page)

Realized volatility This is the standard deviation of daily cum-dividend stock returns over the fiscal year. Alfaro et al.

Implied volatility This is the 252-day average of daily implied volatility values originating from (2018) database OptionMetrics.

Alfaro et al. (2018) database 
Table A2

Correlations

\begin{tabular}{|c|c|c|c|c|c|c|c|c|c|c|c|c|}
\hline & & (1) & (2) & (3) & (4) & (5) & (6) & (7) & (8) & (9) & (10) & $\overline{~(11) ~}$ \\
\hline (1) & AISD & 1 & & & & & & & & & & \\
\hline (2) & TCB & 0.86 & 1 & & & & & & & & & \\
\hline (3) & PSentiment & -0.05 & -0.03 & -0.00 & 1 & & & & & & & \\
\hline (4) & Relationship dummy & -0.11 & -0.10 & -0.01 & -0.01 & 1 & & & & & & \\
\hline (5) & Covenant dummy & 0.12 & 0.07 & 0.60 & 0.00 & 0.01 & 1 & & & & & \\
\hline (6) & Maturity & 0.08 & 0.12 & 0.16 & 0.03 & -0.03 & 0.17 & 1 & & & & \\
\hline (7) & Firm size & -0.31 & -0.22 & -0.34 & -0.01 & 0.10 & -0.30 & -0.18 & 1 & & & \\
\hline (8) & NYSE & -0.18 & -0.19 & -0.08 & -0.04 & 0.08 & -0.05 & -0.04 & 0.40 & 1 & & \\
\hline (9) & Profitability & -0.12 & -0.12 & 0.05 & 0.11 & -0.00 & 0.08 & 0.08 & -0.15 & -0.00 & 1 & \\
\hline (10) & MTB & -0.18 & -0.12 & 0.00 & 0.14 & -0.01 & 0.03 & 0.02 & -0.19 & -0.10 & 0.51 & 1 \\
\hline (11) & Bank size & -0.01 & 0.03 & -0.12 & -0.03 & 0.02 & -0.17 & -0.07 & 0.06 & -0.05 & -0.23 & -0.04 \\
\hline
\end{tabular}




\section{Table A3}

Political sentiment and foreign operation, controlling for political risk.

The dependent variable is AISD — all-in-spread-drawn (basis points) — is the sum of spread over LIBOR plus the facility fee. Definitions of all variables along with their sources are in appendix table A1. Robust standard errors clustered by bank and $t$-statistics are reported in parentheses. Significance at the $1 \%, 5 \%$, and $10 \%$ level is indicated by $* * *, * *$, and *, respectively.

\begin{tabular}{|c|c|c|c|c|}
\hline & (1) & (2) & (3) & (4) \\
\hline PSentiment & $\begin{array}{c}-8.295^{* * *} \\
(-4.31)\end{array}$ & $\begin{array}{c}-5.535 * * * \\
(-3.42)\end{array}$ & $\begin{array}{c}-7.213 * * * \\
(-4.95)\end{array}$ & $\begin{array}{c}-8.499 * * * \\
(-3.11)\end{array}$ \\
\hline PRisk & $\begin{array}{l}0.738 \\
(0.99)\end{array}$ & $\begin{array}{l}1.098 \\
(1.50)\end{array}$ & $\begin{array}{l}1.441^{*} \\
(1.97)\end{array}$ & $\begin{array}{c}2.365^{* * * *} \\
(3.41)\end{array}$ \\
\hline No. countries MNE operates & $\begin{array}{c}-1.902 * * * \\
(-8.87)\end{array}$ & & & \\
\hline PSentiment $(\mathrm{x})$ No. countries MNE operates & $\begin{array}{c}0.748 * * * \\
(5.95)\end{array}$ & & & \\
\hline No. subsidiaries & & $\begin{array}{c}-0.100 * * \\
(-2.13)\end{array}$ & & \\
\hline PSentiment (x) No. subsidiaries & & $\begin{array}{c}0.153 * * * \\
(3.73)\end{array}$ & & \\
\hline Foreign economies of scale & & & $\begin{array}{c}-6.476 * * * \\
(-5.68)\end{array}$ & \\
\hline PSentiment (x) Foreign economies of scale & & & $\begin{array}{c}5.382 * * * \\
(8.86)\end{array}$ & \\
\hline Sub. country political polarization & & & & $\begin{array}{l}0.864 \\
(0.44)\end{array}$ \\
\hline PSentiment (x) Sub. country political polarization & & & & $\begin{array}{c}4.829 * * * \\
(2.83)\end{array}$ \\
\hline Relationship dummy & $\begin{array}{c}-6.493 * * * \\
(-3.28)\end{array}$ & $\begin{array}{c}-6.627 * * * \\
(-3.31)\end{array}$ & $\begin{array}{c}-6.421 * * * \\
(-3.29)\end{array}$ & $\begin{array}{c}-6.934 * * * \\
(-3.29)\end{array}$ \\
\hline Covenant dummy & $\begin{array}{l}13.906^{* * * *} \\
(6.58)\end{array}$ & $\begin{array}{c}13.704 * * * \\
(6.41)\end{array}$ & $\begin{array}{c}12.734 * * * \\
(5.99)\end{array}$ & $\begin{array}{c}11.370 * * * \\
(5.49)\end{array}$ \\
\hline Maturity & $\begin{array}{l}-0.259 \\
(-1.20)\end{array}$ & $\begin{array}{l}-0.261 \\
(-1.22)\end{array}$ & $\begin{array}{l}-0.251 \\
(-1.18)\end{array}$ & $\begin{array}{l}-0.197 \\
(-0.94)\end{array}$ \\
\hline Firm size & $\begin{array}{c}-15.916^{* * *} \\
(-13.42)\end{array}$ & $\begin{array}{c}-19.424 * * * \\
(-13.78)\end{array}$ & $\begin{array}{c}-19.575 * * * \\
(-15.73)\end{array}$ & $\begin{array}{c}-21.329 * * * \\
(-17.07)\end{array}$ \\
\hline NYSE & $\begin{array}{l}11.021^{* * *} \\
(2.71)\end{array}$ & $\begin{array}{c}8.695 * * \\
(2.02)\end{array}$ & $\begin{array}{c}9.199 * * \\
(2.17)\end{array}$ & $\begin{array}{c}9.370^{* *} \\
(2.23)\end{array}$ \\
\hline Profitability & $\begin{array}{c}-77.125^{* * *} \\
(-8.13)\end{array}$ & $\begin{array}{c}-79.722 * * * \\
(-8.34)\end{array}$ & $\begin{array}{c}-83.998 * * * \\
(-8.41)\end{array}$ & $\begin{array}{c}-84.686^{* * * *} \\
(-9.18)\end{array}$ \\
\hline MTB & $\begin{array}{c}-17.985 * * * \\
(-14.55)\end{array}$ & $\begin{array}{c}-18.724 * * * \\
(-14.41)\end{array}$ & $\begin{array}{c}-18.947 * * * \\
(-14.51)\end{array}$ & $\begin{array}{c}-17.941 * * * \\
(-14.49)\end{array}$ \\
\hline Bank size & $\begin{array}{c}-0.37 \\
(-0.73)\end{array}$ & $\begin{array}{l}-0.296 \\
(-0.59)\end{array}$ & $\begin{array}{c}-0.18 \\
(-0.36)\end{array}$ & $\begin{array}{l}-0.353 \\
(-0.69)\end{array}$ \\
\hline Observations & 9,552 & 9,552 & 9,552 & 9,461 \\
\hline Adjusted $\mathrm{R}^{2}$ & 0.547 & 0.542 & 0.546 & 0.538 \\
\hline Cluster & Bank & Bank & Bank & Bank \\
\hline Bank FE & $\sqrt{ }$ & $\sqrt{ }$ & $\sqrt{ }$ & $\sqrt{ }$ \\
\hline Year FE & $\sqrt{ }$ & $\sqrt{ }$ & $\sqrt{ }$ & $\sqrt{ }$ \\
\hline SIC3 FE & $\sqrt{ }$ & $\sqrt{ }$ & $\sqrt{ }$ & $\sqrt{ }$ \\
\hline Purpose FE & $\sqrt{ }$ & $\sqrt{ }$ & $\sqrt{ }$ & $\sqrt{ }$ \\
\hline Loan type FE & $\sqrt{ }$ & $\sqrt{ }$ & $\sqrt{ }$ & $\sqrt{ }$ \\
\hline
\end{tabular}


Table A4

Political sentiment and foreign operation, controlling for political risk and including firm fixed effects.

The dependent variable is AISD — all-in-spread-drawn (basis points) — is the sum of spread over LIBOR plus the facility fee. Definitions of all variables along with their sources are in appendix table A1. Robust standard errors clustered by bank and $t$-statistics are reported in parentheses. Significance at the $1 \%, 5 \%$, and $10 \%$ level is indicated by $* * *, * *$, and *, respectively.

\begin{tabular}{lcccc}
\hline \hline & $\mathbf{( 1 )}$ & $\mathbf{( 2 )}$ & $\mathbf{( 3 )}$ & $\mathbf{( 4 )}$ \\
\hline PSentiment & $-10.906 * * *$ & $-6.104 * * *$ & $-6.746 * * *$ & $-9.532 * * *$ \\
PRisk & $(-5.17)$ & $(-3.75)$ & $(-4.47)$ & $(-3.08)$ \\
& 0.341 & 0.622 & 1.052 & 1.062 \\
& $(0.27)$ & $(0.50)$ & $(0.85)$ & $(0.83)$
\end{tabular}

No. countries MNE operates

PSentiment (x) No. countries MNE operates

$0.996 * * *$

(6.54)

No. subsidiaries

PSentiment (x) No. subsidiaries

$0.188 * * *$

(4.91)

Foreign economies of scale

PSentiment (x) Foreign economies of scale

$4.421 * * *$

(6.07)

Sub. country political polarization

PSentiment (x) Sub. country political polarization

$5.655^{* * *}$

Relationship dummy

$-4.142 * * *$

$-3.980 * *$

(3.22)

Covenant dummy

$(-2.65)$

$(-2.52)$

$-4.009 * *$

$10.782 * * *$

$10.290 * * *$

$-3.556^{* *}$

$(-2.40)$

(4.88)

(4.78)

$(-2.28)$

$8.598 * * *$

Maturity

0.036

0.035

$9.765^{* * *}$

(4.30)

(0.18)

(0.18)

(4.55)

0.098

Firm size

$-21.826 * * *$

$-20.389 * *$

(0.10)

(0.50)

$(-2.69)$

$(-2.52)$

$-19.988 * *$

$-18.914 * *$

NYSE

$10.800 * * *$

$10.586^{* * *}$

$(-2.48)$

$(-2.43)$

(3.32)

Profitability

$-46.974 * * *$

(3.26)

$10.123 * * *$

$8.278 * *$

(3.13)

$(-5.18)$

$-44.494 * * *$

$-45.255^{* * *}$

MTB

$-11.088 * * *$

$(-4.82)$

(-4.94)

$-44.549 * *$

MT

$(-2.84)$

$-10.934 * * *$

$-10.649 * * *$

$(-4.80)$

Bank size

$-0.398$

(-2.77)

$(-2.66)$

$-11.039 * * *$

Observations

(-1.01)

$-0.329$

$-0.22$

$(-2.84)$

Adjusted $\mathrm{R}^{2}$

9,524

(-0.86)

(-0.59)

$-0.446$

Cluster

Bank FE

Year FE

SIC3 FE

Purpose FE

Loan type FE

Firm FE

0.737

9,524
0.735

9,524

(-1.14)

Bank

Bank

Bank

9,433
0.73

$\begin{array}{ll}\sqrt{ } & \sqrt{ } \\ \sqrt{ } & \sqrt{ } \\ \sqrt{ } & \sqrt{ } \\ \sqrt{ } & \sqrt{ } \\ \sqrt{ } & \sqrt{ } \\ \sqrt{ } & \sqrt{ }\end{array}$

$\sqrt{ }$

Bank

$\checkmark$

$\sqrt{ }$

$\sqrt{ }$

$\sqrt{ }$

$\sqrt{ }$

$\sqrt{ }$ 